\title{
A Modern Fiduciary Theory of the Necessary \& Proper Clause
}

\author{
Philip J. Levitz ${ }^{1}$
}

This Article offers a new originalist account of the Necessary and Proper Clause, with important implications for the Supreme Court's pending decision on the constitutionality of the Affordable Care Act's individual mandate. In United States v. Comstock, the Supreme Court recently offered a substantial rethinking of the Necessary and Proper Clause, for perhaps the first time since McCulloch $v$. Maryland. Underlying the Court's Comstock decision are two puzzles. First, there is a puzzle on the surface of the opinion as to how to apply Justice Breyer's novel five "considerations" in future cases, which this Article demonstrates has already left lower courts deeply confused, notably in the cases on the constitutionality of the Affordable Care Act. Second, Comstock brings back to the surface a deeper puzzle that has sat dormant in Necessary and Proper Clause jurisprudence from the beginning: the puzzle of what it really means for congressional legislation to be rationally related to an enumerated constitutional end.

This Article seeks to solve both puzzles together by proposing a modern fiduciary theory of the Necessary and Proper Clause that provides meaning to Breyer's considerations and clarifies the nature of a rational relation between legislated means and enumerated ends. After canvassing the range of possible readings of Comstock and its means-end fit test, the Article draws on newly uncovered history of the fiduciary and agency law roots of the Necessary and Proper Clause to argue that the means-end test that is the best reading of Comstock would ask whether Congress, in legislating, is acting as a proper fiduciary of the people of the United States, within the context of its enumerated powers. Using the Affordable Care Act as a case study, the Article demonstrates that the modern fiduciary theory brings to bear a new and valuable toolset in interpreting the Act, and ultimately makes clear that the Necessary and Proper Clause should not pose a challenge to the law's constitutionality.

\footnotetext{
${ }^{1}$ J.D. Candidate, 2012, Yale Law School. My sincere thanks to Heather Gerken for advising my work on this Article, and for all her very helpful comments along the way. I would also like to thank Jack Balkin, Oona Hathaway, Daniel Hemel, and John Mikhail for their thoughtful comments and suggestions, and, finally, Miles Farmer, for sparking the conversation that led me to the idea for this Article.
} 


\section{TABLE OF CONTENTS}

I. U.S. V. Comstock AND the ReEmergence of the NeCEssary and Proper Clause.

A. The Majority's Two Puzzles ................................................................... 8

1. The New Puzzle: Breyer's Five Factors …………………………...... 9

2. The Enduring Puzzle: Means-End Fit................................................ 12

B. Two Concurrences.............................................................................. 14

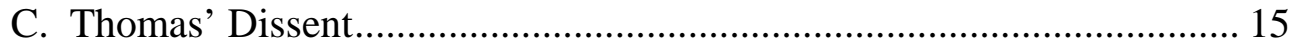

II. THE NECESSARY AND PROPER ClaUSE IN DiSARRAY ..................................... 16

A. Sex Offender Cases and Beyond............................................................ 16

B. The Affordable Care Act Cases ............................................................ 19

III. Fixing the Necessary And Proper Clause After Comstock .................. 22

A. Back to Basics: History of the Clause ........................................................ 23

3. Roots in Fiduciary and Agency Law .............................................. 24

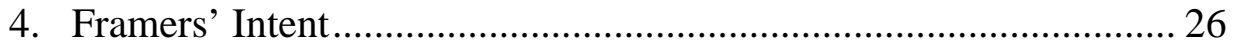

B. McCulloch as Defining (But Incomplete) Interpretation ........................ 29

C. Three Readings of the Necessary and Proper Clause After Comstock .. 31

1. "Rational Basis with Bite"............................................................. 32

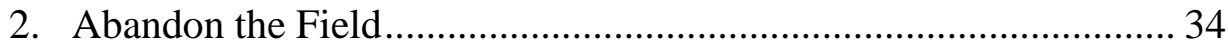

3. An Intermediate Option .............................................................. 35

IV. A Modern Fiduciary Theory of the Necessary \& Proper Clause ..... 37

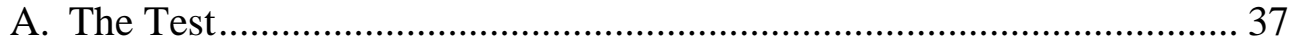

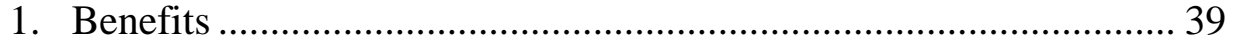

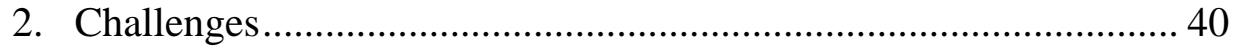

B. Case Study: The Affordable Care Act........................................................ 41

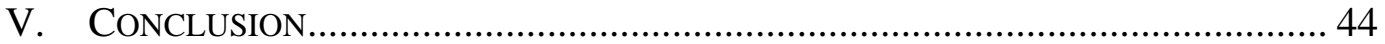


For nearly two centuries, as battles were waged over clause after clause of the Constitution - the Commerce Clause invigorated (and cabined), the Due Process Clause substantiated (and unsubstantiated), the Equal Protection Clause applied to many a new suspect class — one crucial clause sat quietly unquestioned. The Necessary and Proper Clause, as every first-year constitutional law student learns, is simple. In the famous words of Chief Justice Marshall in McCulloch v. Maryland: "Let the end be legitimate, let it be within the scope of the constitution, and all means which are appropriate, which are plainly adapted to that end, which are not prohibited, but consist with the letter and spirit of the constitution, are constitutional.",2

Yet, with little fanfare, the Supreme Court recently presented a substantial rethinking of the Necessary and Proper Clause, for perhaps the first time since McCulloch. Suddenly, the Court offered five vague "considerations" that might form the basis of an entirely new test of what Congressional action is in fact "necessary and proper." (Or might not.) Suddenly, Marshall's elegant and simple test looked much more complex.

In United States $v$. Comstock, ${ }^{3}$ the Court upheld the constitutionality of a federal statute allowing a court to order civil commitment of "sexually dangerous" individuals beyond the date the prisoners would otherwise be released at the conclusion of their criminal sentences. The Court justified this striking exercise of federal power by citing the Necessary and Proper Clause. In support of his conclusion, Justice Breyer, writing for the Court, noted the breadth of the Necessary and Proper Clause; the long history of federal involvement in the relevant area; the sound reasons for the statute's enactment; the statute's accommodation of state interests; and the statute's narrow scope. ${ }^{4}$ None of these considerations had previously been part of the test for constitutionality under the Necessary and Proper Clause. Further, Justice Breyer rejected a one-step limit to the connection, under the Clause, between means of congressional legislation and enumerated constitutional ends.

The Court's Comstock decision raises more questions than it answers: must all Breyer's considerations be satisfied for a necessary and proper exercise of Congress' authority? Must any of them? Are they really just "considerations" underlying one particular decision or do they constitute some form of new test? If they do point to a new test, how should that test be applied in the innumerable other contexts in which Congress legislates? And, however the five factors are weighed, what are the proper limits on the fit between legislated means and enumerated ends?

\footnotetext{
${ }^{2}$ McCulloch v. Maryland, 17 U.S. (4 Wheat.) 316, 421 (1819).

${ }^{3} 130$ S. Ct. 1949 (2010).

${ }^{4}$ See, e.g., id. at 1965.
} 
This Article aims to begin answering these questions-which have garnered little attention to date $\mathrm{s}^{5}$ and give content to the Comstock "test." Fortunately, the time is particularly ripe for a reexamination of the application of the Necessary and Proper Clause in light of recent research on the history of the Clause by Gary Lawson, Geoffrey Miller, Robert Natelson, and Guy Seidman. ${ }^{6}$ This Article will expand upon their historical conclusions to consider how best to provide meaning for Breyer's test that is informed by the Clause's original meaning. The analysis will not, however, be purely originalist, in that it will apply original meaning to the contemporary Necessary and Proper Clause in a dynamic way, employing a kind of "living originalism."7 Ultimately, the Article will propose a modern fiduciary theory of the Clause, and will thus contribute to growing appreciation of fiduciary models of law and democracy. ${ }^{8}$

The analysis is also timely in light of the Supreme Court's recent decision to grant certiorari on the question of the constitutionality of the Patient Protection

\footnotetext{
${ }^{5}$ See, e.g., Linda Greenhouse, The Revolution Next Time?, N.Y. TimES (Dec. 16, 2010, 8:00 PM), http://opinionator.blogs.nytimes.com/2010/12/16/the-revolution-next-time/ ("The Comstock decision did not receive a great deal of public attention when it was issued.”). Since Greenhouse's observation, a few articles summarizing and offering limited commentary on the opinion have been published. See, e.g., Tucker Culbertson, After Comstock: Equal Protection Challenges to the Civil Commitment Provisions of the Adam Walsh Child Protection and Safety Act, 61 SYRACUSE L. Rev. 427 (2011); Garrick B. Pursley, Penal Deference and Other Oddities in United States v. Comstock, 6 Duke J. Const. L. \& PUB. Pol'Y. 98 (2010); Ilya Shapiro \& Trevor Burrus, Not Necessarily Proper: Comstock's Errors and Limitations, 61 SYRACUSE L. REV. 413 (2011); Ilya Somin, Taking Stock of Comstock: The Necessary and Proper Clause and the Limits of Federal Power, 2010 Cato Sup. Cт. Rev. 239; see also Lauren Kulpa, Note, United States v. Comstock: The Next Chapter in the Struggle Between State and Congressional Power, 44 LoY. L.A. L. REV. 1145 (2011). Commentary on the Patient Protection and Affordable Care Act also has begun to pick up on the case's relevance. See, e.g., Mark A. Harris, Commerce Clause Challenges to Health Care Reform, 159 U. Pa. L. Rev. 1825 (2011); Andrew Koppelman, Bad News for Mail Robbers: The Obvious Constitutionality of Health Care Reform, 121 YALE L.J. OnLINE 1 (2011), http://www.yalelawjournal.org/the-yale-law-journal-pocket-part/constitutional-law/bad-news-formail-robbers:-the-obvious-constitutionality-of-health-care-reform/; Gary Lawson \& David B. Kopel, Bad News for Professor Koppelman: The Incidental Unconstitutionality of the Individual Mandate, 121 YALE L.J. ONLINE 267 (2011), http://yalelawjournal.org/the-yale-law-journalpocket-part/supreme-court/bad-news-for-professor-koppelman:-the-incidental-unconstitutionalityof-the-individual-mandate/.

${ }^{6}$ Of particular note is a recently published edited volume with contributions from these authors that provides the first book-length attempt at a comprehensive history of the clause. GARY LAWSON ET AL., THE ORIGINS OF THE NECESSARY AND PROPER ClAuse (2010).

${ }^{7}$ See JACK M. BALKIN, LIVING ORIGINALISM (2011).

${ }^{8}$ See, e.g., Evan J. Criddle, Fiduciary Foundations of Administrative Law, 54 UCLA L. REV. 117 (2006); Evan J. Criddle \& Evan Fox-Decent, A Fiduciary Theory of Jus Cogens, 34 YALE J. INT'L L. 331 (2009); Evan Fox-Decent, The Fiduciary Nature of State Legal Authority, 31 QuEEN's L.J. 259 (2005); Evan Fox-Decent \& Evan J. Criddle, The Fiduciary Constitution of Human Rights, 15 LEGAL ThEORY 301 (2009); David L. Ponet \& Ethan J. Leib, Fiduciary Law's Lessons for Deliberative Democracy, 91 B.U. L. REV. 1249 (2011).
} 
and Affordable Care Act (PPACA). ${ }^{9}$ After Comstock shook up the settled doctrine of the Clause, the debates on the constitutionality of the PPACA have drawn heavily on arguments about whether the law's individual insurance mandate is a necessary and proper exercise of Congress' power. ${ }^{10}$ Of course, the PPACA debates are but one of many disagreements on the constitutionality of a congressional exercise of legislative power likely to remain open until a clearer "necessary and proper" standard is reestablished.

This Article will proceed in four parts. Part I will provide an overview of the Comstock decision and the reemergence of Necessary and Proper Clause jurisprudence that it engendered. After briefly summarizing the history of the case, it will proceed to identify two puzzles arising from Breyer's majority opinion. First, it will consider Breyer's five novel factors, and the puzzle of how these factors ought to be read moving forward. Second, it will identify a deeper puzzle that has sat dormant in Necessary and Proper Clause jurisprudence from the beginning, but that Comstock brought back to the fore: the puzzle of what it really means for congressional legislation to be, in Chief Justice Marshall's words, "plainly adapted" to an enumerated constitutional end. ${ }^{11}$ Part I will also summarize Justice Alito and Justice Kennedy's concurrences, as well as Justice Thomas' vigorous dissent, which, among other complaints, attacked Breyer's opinion for precisely the vagueness this Article seeks to remedy.

Part II will take a preliminary look at Necessary and Proper Clause jurisprudence since Comstock. This Part will ask how lower courts have interpreted the limits of the Necessary and Proper Clause in authorizing congressional action, in light of Breyer's opinion, including his five factors. It will demonstrate that there is substantial confusion in the lower courts on the application of the majority's test, and that the confusion has been especially manifest in the lower court opinions on the constitutionality of the PPACA. It will also argue that some lower courts seem to be capitalizing on the vagueness of Breyer's factors to justify whatever conclusion the judges may prefer.

Part III will consider possibilities for curing the ambiguity inherent in the Comstock decision and bringing clarity to Necessary and Proper Clause jurisprudence, drawing on the history of the Clause and its interpretation. It will

\footnotetext{
${ }^{9}$ Pub. L. No. 111-148, 124 Stat. 119-1025 (2010).

${ }^{10}$ See, e.g., Florida v. U.S. Dep’t of Health \& Human Servs., No. 3:10-cv-91-RV/EMT, 2011 WL 3519178 (11th Cir. Aug. 12, 2011), cert. granted, 80 U.S.LW. 3198 (U.S. Nov. 14, 2011) (No. 11393), 80 U.S.L.W 3199 (U.S. Nov. 14, 2011) (No. 11-398), cert. granted in part, 2011 WL 5515165 (U.S. Nov. 14, 2011) (No. 11-400); Thomas More Law Center v. Obama, 651 F.3d 529 (6th Cir. 2011); Florida ex rel. Bondi v. U.S. Dep’t of Health \& Human Servs., 780 F. Supp. 2d 1256 (N.D. Fla. 2011), aff'd in part, rev'd in part sub nom. Florida v. U.S. Dep’t of Health \& Human Servs, 648 F.3d 1235 (11th Cir. 2011); Virginia ex rel. Cuccinelli v. Sebelius, 728 F. Supp. 2d 768 (E.D. Va. 2010), vacated, 656 F.3d 253 (4th Cir. 2011).

${ }^{11}$ McCulloch v. Maryland, 17 U.S. (4 Wheat.) 316, 421 (1819).
} 
start by returning to the roots of the Clause in corporate, administrative, and especially fiduciary law principles. This historical analysis will indicate that "necessary" seems, at the time of the founding, to have been a reference to fit between a legislated means and an enumerated constitutional end, while "proper"-and particularly the "necessary and proper" construction as a wholefollowed a typical colonial agency law pattern referring to conformance with fiduciary norms expected of public officials. This Part will also demonstrate that the Framers meant to incorporate this fiduciary vision in the Necessary and Proper Clause, and Chief Justice Marshall's opinion in McCulloch implicitly drew on the very same principles.

This historical backdrop will provide a starting point for informing a test that gives additional meaning and clarity to Justice Breyer's Comstock approach, and ideally solves both the five-factor and the means-end fit puzzles of Breyer's opinion. Three basic possibilities might be envisioned. A more aggressive interpretation of the Necessary and Proper Clause after Comstock might apply a "rational basis with bite"-type analysis that suggests that the fit between legislated means and enumerated end must be a truly reasonable one for the congressional action to be constitutional. On the other end of the spectrum, if Breyer's factors are read only as vague considerations, it seems most any minimal fit between means and ends could suffice. The Court has, in this reading, virtually "abandoned the field" of constraining Congress' authority under the Necessary and Proper Clause. Finally, there may be a number of possible intermediate options.

This Part suggests that the most appropriate such intermediate position would be one that is informed by the historical fiduciary principles on which the Necessary and Proper Clause is based. In particular, this Article proposes the following means-ends test: is Congress acting as a proper fiduciary of the people of the United States, within the context of its enumerated powers?

Part IV elaborates on this modern fiduciary theory of the Necessary and Proper Clause, its benefits, and some potential challenges. It concludes that the modern fiduciary theory offers both effective moderation between the two extremes of a test with too much "bite" and an empty test abandoning the field, and flexibility over time, while maintaining roots in the history of the Necessary and Proper Clause. The test therefore presents a robust and consistent way to fill the gaps in Necessary and Proper Clause interpretation left by Comstock's ambiguities, clarifying the meaning of a reasonable fit between legislated means and enumerated ends and the way Breyer's five factors ought to be understood. This theory is then tested in the case of the PPACA. It is demonstrated that the modern fiduciary theory brings to bear a new and valuable toolset in interpreting the PPACA, making clear that-given Congress' proper action as a fiduciary of the people of the United States in passing the legislation-the Necessary and 
Proper Clause should not pose a challenge to the law's constitutionality. A brief conclusion follows.

\section{U.S. V. COMSTOCK AND THE REEMERGENCE OF THE NECESSARY AND Proper Clause}

In July 2006, President Bush signed into law the Adam Walsh Child Protection and Safety Act, a major statute aimed at fighting sexual exploitation of children. ${ }^{12}$ Senator Orrin Hatch described the law as the "most comprehensive child crimes and protection bill in our Nation's history."13 Buried within the statute was a striking provision, $\S 4248$, under which the Attorney General or his designee could certify an incarcerated individual as "sexually dangerous," even if the individual had not been convicted of a sexual offense. ${ }^{14}$ Once so certified, the sexually dangerous individual could, at the Attorney General's discretion, be civilly detained beyond his originally imposed criminal sentence, either in a federal facility, or, if the state in which the individual lived or was convicted was willing, a facility of that state. ${ }^{15}$

When the Adam Walsh Act was passed, Graydon Comstock was a few months away from the end of his federal prison sentence for receipt of child pornography. ${ }^{16}$ Soon after the statute passed, Comstock was designated a sexually dangerous individual and was set to be civilly detained beyond his scheduled release date. ${ }^{17}$ Comstock, and a number of similarly situated plaintiffs whose cases were consolidated, brought suit in the Eastern District of North Carolina, challenging the constitutionality of their continued detention. ${ }^{18}$ The district court sided with Comstock, finding that the civil commitment scheme was not sufficiently tied to any enumerated federal power to be justified, and was therefore an unconstitutional exercise of congressional authority. ${ }^{19}$ Judge Motz, writing for a unanimous Fourth Circuit panel, affirmed, holding that neither the

\footnotetext{
${ }^{12}$ Pub. L. No. 109-248, 120 Stat. 587 (2006).

13152 CONG. REC. 8012 (2006).

${ }^{14} 18$ U.S.C. $\S 4248$ (2006).

${ }^{15}$ Id. $\S 4248(\mathrm{~d})$.

${ }^{16}$ United States v. Comstock, 507 F. Supp. 2d 526 (E.D.N.C. 2007).

${ }^{17} \mathrm{Id}$.

${ }^{18} I d$. at 527.

${ }^{19}$ See, e.g., id. at 559 ("Because the civil commitment scheme set forth at 18 U.S.C. § 4248 is not sufficiently tied to the exercise of any enumerated or otherwise identifiable constitutional power of Congress and because $\S 4248$, as currently structured, is not a proper exercise of any power that Congress might constitutionally exercise, this court concludes that 18 U.S.C. $\S 4248$ is unconstitutional.”).
} 
Commerce Clause nor the Necessary and Proper Clause justified Congress' passage of the civil commitment provision. ${ }^{20}$

As a circuit split emerged, ${ }^{21}$ the Supreme Court granted a writ of certiorari, and was thus faced with a rare head-on challenge to Congress' authority to legislate under the Necessary and Proper Clause. Justice Breyer, writing for the Court, reversed the district court and the court of appeals with an opinion presenting a surprising rethinking of a Clause largely settled since McCulloch. ${ }^{22}$ The remainder of this Part will review the Supreme Court's Comstock decision, including the two concurrences and Justice Thomas' dissent. It will focus in particular on two puzzles emerging from the majority opinion, which must be solved in order to bring structure and consistency to Necessary and Proper Clause jurisprudence.

\section{A. The Majority’s Two Puzzles}

Justice Breyer's opinion for the majority in Comstock is notable, first, for the novel five factors it laid out for evaluating whether the civil commitment provision that Congress passed in $\S 4248$ of the Adam Walsh Act was in fact "necessary and proper" for carrying out an enumerated constitutional power. Whether and how to apply these factors in future cases is the first puzzle of Breyer's opinion. The opinion is, however, also notable for its conclusion that there is no inherent limit to the number of inferential "steps" "between an enumerated power and an Act of Congress," but rather that only a rational basis is needed for the relationship between the enumerated power and the congressional act. $^{23}$ This conclusion brings attention to a deeper, unresolved puzzle in

\footnotetext{
${ }^{20}$ United States v. Comstock, 551 F.3d 274, 280 (4th Cir. 2009) ("Supreme Court precedent thus compels the conclusion that $\S 4248$ does not constitute a valid exercise by Congress of its Commerce Clause power. To construe $\S 4248$ as within such power would encroach on the police and parens patriae powers reserved to the sovereign states, conflating 'what is truly national and what is truly local." (internal citation omitted)); id. ("What is less understandable is the Government's heavy reliance on the Necessary and Proper Clause, standing alone, as a source of congressional power. Of course, as the Government contends at length, the Necessary and Proper Clause reaches broadly, but it does so only to effectuate powers specifically enumerated in the Constitution.”); see also id. at 283 (“[T]he Government maintains that the Necessary and Proper Clause justifies $\S 4248$ because it retains the 'power to prosecute' all persons in its custody charged with criminal offenses. But the Government has already charged, tried, and convicted Comstock ... of all alleged federal crimes; it retains no power to prosecute ....”).

${ }^{21}$ Compare Comstock, 551 F.3d 274, with United States v. Volungas, 593 F.3d 1 (1st Cir. 2010) (upholding the constitutionality of $\S 4248$, after cert was granted in Comstock), and United States v. Tom, 565 F.3d 497 (8th Cir. 2009) (upholding the constitutionality of the statute between the filing of Comstock's initial cert petition and his cert-stage reply brief).

${ }^{22}$ See United States v. Comstock, 130 S. Ct. 1949 (2010).

${ }^{23}$ Id. at 1964.
} 
Necessary and Proper Clause jurisprudence: what exactly makes for a rational fit between legislated means and enumerated end? This Section explores Breyer's opinion and its two puzzles in detail, to set the stage for possible solutions.

\section{The New Puzzle: Breyer's Five Factors}

In his opinion for the majority, Justice Breyer "ask[ed] ... whether the Federal Government, exercising its enumerated powers, may enact such a statute [as § 4248]," and concluded that it could. ${ }^{24}$ The Court "base[d] this conclusion on five considerations, taken together."25

First, the majority noted that "the Necessary and Proper Clause grants Congress broad authority to enact federal legislation," citing to McCulloch, among other sources. ${ }^{26}$ The Court said Congress "possesses broad authority" to criminalize, imprison, and enact laws governing prisons and prisoners "in the course of 'carrying into Execution' the enumerated powers 'vested by' the 'Constitution in the Government of the United States'-authority granted by the Necessary and Proper Clause." 27

Second, the Court considered that "the civil-commitment statute before us constitutes a modest addition" to the existing statutory scheme of "federal prisonrelated mental health statutes that have existed for many decades." While the majority "recognized that even a longstanding history does not demonstrate a statute's constitutionality," it also noted (somewhat circularly) that such history could be helpful in determining "the reasonableness of the relation between the new statute and pre-existing federal interests.,28

Third, the Court indicated that $\S 4248$ was based on sound reasons for enactment. That is, the provision was deemed a reasonable exercise of the federal government's role as custodian of its prisoners. ${ }^{29}$

Fourth, the majority considered the statute's accounting for state interests, holding that it sufficiently preserved these interests, and posed no Tenth Amendment problem. ${ }^{30}$

Finally, fifth, the Court pointed to the narrowness of the statute's scope and found that "the links between $\S 4248$ and an enumerated Article I power [were] not too attenuated."31

${ }^{24}$ Id. at 1956.

${ }^{25} \mathrm{Id}$.

${ }^{26}$ See id. at 1956-57 (quoting McCulloch, 17 U.S. (4 Wheat.) at 421).

${ }^{27} \mathrm{Id}$. at 1958 (internal citation omitted).

${ }^{28} \mathrm{Id}$.

${ }^{29}$ Id. at 1961.

${ }^{30} \mathrm{Id}$. at 1962.

${ }^{31} I d$. at 1963. 
Yet the majority said nothing about where these considerations came from. They certainly were not understood, or cited, as existing considerations in Necessary and Proper Clause jurisprudence. ${ }^{32}$ Nor did the majority say what "taking together" these considerations really meant. Rather, it left courts applying the Necessary and Proper Clause with a new puzzle as to whether the vague considerations were simply justifications for the particular decision in Comstock, or criteria to be applied in future cases. If the latter, the opinion left further questions as to whether the considerations should be applied as a test, perhaps requiring all five, or at least most, of the factors to be met for legislation to be necessary and proper, or whether satisfying a couple of the criteria might be sufficient. $^{33}$

It is worth noting here at the outset that Justice Breyer's general jurisprudential approach suggests the considerations were most likely meant to be considerations underlying the decision in Comstock itself, and not a rigorous new necessary and proper test to be applied consistently in future cases. Justice Breyer has become well known for his pragmatism, ${ }^{34}$ which is expounded in the two books Breyer has written as a Justice, Active Liberty and Making Our Democracy Work. $^{35}$ Breyer wrote in Active Liberty that a goal of judging should be "law that helps a community of individuals democratically find practical solutions to

\footnotetext{
${ }^{32}$ See, e.g., Somin, supra note 5, at 248 ("[T] precedent, including Chief Justice John Marshall's landmark decision in M'Culloch $v$. Maryland.").

${ }^{33}$ See id. at 244 ("Does the government still win if, say, only three of the five considerations support its position? If not, the five-part test significantly undercuts the pro-government implications of the Court's use of the rational basis test. . . U Unfortunately, the Comstock Court says very little about how the five-part test should be applied to future cases."); see also Pursley, supra, note 5, at 112-13 ("The majority did not provide a readily generalizable limitation on Congress's power to legislate in furtherance of implied powers. The meaning of the five-factor test remains to be worked out.").

${ }^{34}$ See, e.g., Paul Gewirtz, The Pragmatic Passion of Stephen Breyer, 115 YALE L.J. 1675 (2006); Richard J. Pierce, Jr., Justice Breyer: Intentionalist, Pragmatist, Empiricist, 8 ADMIN. L.J. 747 (1995); Cass R. Sunstein, Justice Breyer's Democratic Pragmatism, 115 YALE L.J. 1719 (2006); Jeffrey Rosen, Op-Ed, Two Kinds of Pragmatist, L.A. TimES, Oct. 23, 2005, http://articles.latimes.com/2005/oct/23/books/bk-rosen23. Justice Breyer's academic work before ascending to the bench was also recognized for its pragmatism. See Sunstein, supra, at 1719-20 (“As a law professor at Harvard Law School, .... . [Breyer’s] important work in [administrative law] was marked above all by its unmistakably pragmatic foundations. In an influential book, Breyer emphasized that regulatory problems were 'mismatched' to regulatory tools; he urged that an understanding of the particular problem that justified regulation would help in the selection of the right tool.").

${ }^{35}$ See generally STEPHEN BREyer, MAKIng OUR DeMOCRACy WORK: A JudGE's VieW (2011); STEPHEN BREYER, ACTIVE LIBERTY: INTERPRETING A DEMOCRATIC CONSTITUTION (2008).
} 
important contemporary social problems.”36 For Breyer, judges should attempt to consider and balance all the relevant factors in a given case. ${ }^{37}$

In addition, as Jeffrey Rosen has recognized, Justice Breyer's pragmatism is a deferential one: "[f]or a modest justice with a sense of humility, such as Breyer, pragmatism seems, in most cases, a manifesto for judicial restraint." ${ }^{\text {,3 }}$ In fact, contrary to the rhetoric of those deploring liberal "judicial activism," multiple studies have found Justice Breyer to be the most deferential member of the Court, voting to overturn congressional statutes less often than any other Justice. $^{39}$ In Active Liberty, Breyer noted that his interpretive tradition "calls for judicial restraint, basing that call upon both technical circumstance and democratic value."40 Breyer's thinking hearkens back to the blend of deference and pragmatism characteristic of Justices Brandeis and Holmes. ${ }^{41}$ Like them,

36 Breyer, ACTIVE LiBERTy, supra note 35, at 12; see also id. at 19 (discussing Breyer's understanding of the Framers' commitment to "democratic principle[s] that would prove practically workable and that also, as a practical matter, would help protect individuals against oppression”).

37 See id. at 109 (stating that Breyer's interpretive tradition "hesitates to rely upon any single theory or grand view of law, of interpretation, or of the Constitution.”); see also Gewirtz, supra note 34, at 1677 (“[Breyer’s] opinions never rest on unitary principles . . . but invariably draw on multiple sources of meaning. He is not a case-at-a-time judge, but he is always engaged in the detailed particularity of specific cases, and in many ways his distinctive excellence is that he sees that particularity so clearly and can hold in place and attempt to balance the many factors that he sees at stake at particular moments of decision.”).

38 Jeffrey Rosen, Op-Ed, Two Kinds of Pragmatist, L.A. TiMES, Oct. 23, 2005, http://articles.latimes.com/2005/oct/23/books/bk-rosen23 (contrasting Breyer's deferential pragmatism with the less deferential pragmatism of Justice O’Connor).

${ }^{39}$ Lori A. Ringhand, Judicial Activism: An Empirical Examination of Voting Behavior on the Rehnquist Natural Court, 24 Const. Comment. 43, 49 (2007) (showing that Breyer cast the fewest votes to declare federal statutes unconstitutional on the Rehnquist Natural Court); see also Thomas J. Miles \& Cass R. Sunstein, Do Judges Make Regulatory Policy? An Empirical Investigation of Chevron, 73 U. CHI. L. REV. 823, 826 (2006) ("Consider also a remarkable fact: Justice Breyer, the Court's most vocal critic of a strong reading of Chevron, is the most deferential justice in practice . . . .”); id. at 831 ("Of the nine justices, Justice[] Breyer . . . [has] the highest validation rates, at 81.8 percent . . . .”); Paul Gewirtz \& Chad Golder, Op-Ed., So Who Are the Activists?, N.Y. TIMES, July 6, 2005, at A23.

${ }^{40}$ BREYER, ACTIVE LIBERTy, supra note 35, at 107; see also Gewirtz, supra note 34, at 1683 ("In cases such as United States v. Lopez, in which the Court has struck down congressional enactments as exceeding Congress's Commerce Clause powers, Breyer has emphasized the importance of deferring to Congress because of its plausible conclusions and comparative advantage in assessing social facts (the empirical detail of his dissent shows him writing in the tradition of Justice Brandeis), and because 'the public has participated in the legislative process at the national level.'” (internal citation omitted)).

41 Justice Breyer cited both Justices a number of times in Active Liberty, and he once gave the Brandeis Lecture at the University of Louisville School of Law, where he argued that Brandeis "was right in urging deference to legislative judgments, when economic regulation and ordinary social legislation is at issue. And he was right that we must continue to use facts and consequences 
Breyer rarely meets a statute he thinks exceeds constitutional bounds, and for the same reasons: "reverence for experts, belief in majority rule, and the need to protect society from itself." 42

After better understanding Breyer's approach to constitutional interpretation, it seems clear that-in the civil commitment provision of the Adam Walsh Act-Justice Breyer saw a federal statute he thought made a sense, and was "necessary and proper" to address a pressing national problem. He therefore wanted to find a practical way to defer to the democratically elected Congress' decision to address that problem, within the bounds of the Constitution. He did so via the opinion's five considerations, weighing these relevant factors, and ultimately upholding the law under the Necessary and Proper Clause. Justice Breyer was almost certainly not, then, attempting to make things difficult for Congress by imposing a five-factor test, but, on the contrary, was looking for all the relevant reasons to uphold $\S 4248$. This inference at least gestures toward a solution to Comstock's first puzzle. Of course, the opinion itself is not so clear, hence the confusion over the five considerations in the lower courts considered in depth below. ${ }^{43}$

\section{The Enduring Puzzle: Means-End Fit}

Breyer's discussion of the last Comstock consideration-narrowness of scope-was especially noteworthy in that, not only did it lay out a consideration that had not previously been explicitly applied, but it also repudiated a tenet of Necessary and Proper Clause theory that had been widely accepted and assumed by Comstock in his brief and at oral argument. ${ }^{44}$ The Court rejected Comstock's

to distinguish permissible, or better, from impermissible or worse, interpretations of the Constitution and of law.” Stephen Breyer, Brandeis Lecture: Justice Brandeis as Legal Seer (Feb.

16 , 2004), available

at

http://www.supremecourt.gov/publicinfo/speeches/viewspeeches.aspx?Filename=sp_02-16-

04.html.

42 David E. Bernstein \& Josh Blackman, Op-Ed, Supreme Court Justice Stephen Breyer Shows Progressive Streak, STAR-LEDGER, http://blog.nj.com/njv_guest_blog/2011/07/supreme_court_justice_stephen.html.

${ }^{43}$ See infra Part II.

${ }^{44}$ See, e.g., Brief for Respondent at 26, United States v. Comstock, 130 S. Ct. 1949 (2010) (No. 08-1224) (“[T]he Necessary and Proper Clause does not demand a nexus to federal 'interests,' 'connections' or 'special relationships'; it demands a nexus to an enumerated power.”); id. at 22 (distinguishing situations in which "[a] clear and unbroken connection exists between these aspects of the criminal justice system and the enumerated power" from the $\S 4248$ situation); Transcript of Oral Argument at 28, United States v. Comstock, 130 S. Ct. 1949 (2010) (No. 081224) (distinguishing Comstock's situation from that of someone not guilty by reason of insanity because "the commitment that flows from a not guilty by reason of insanity verdict is directly linked to the Federal law which brought you into custody in the first place. . . . . [s]o there's a 
argument that "Congress' authority can be no more than one step removed from a specifically enumerated power," despite the Court's assertion in United States $v$. Lopez that it "may not 'pile inference upon inference' in order to sustain congressional action under Article I." " I5 Instead, citing McCulloch, and other precedent including Greenwood v. United States, a prior case upholding the constitutionality of a federal civil commitment scheme, ${ }^{46}$ and Sabri v. United States, a more recent decision upholding legislation on Necessary and Proper Clause grounds, ${ }^{47}$ the majority held that there was no categorical rule limiting Congress to one inferential step from an enumerated power in passage of legislation.

All that was required seemed to be a rational relationship between the legislated means and some end enumerated in the Constitution. ${ }^{48}$ As Ilya Somin has indicated, this poses a serious problem if the Court's logic is taken to an extreme: "[T]hen the Necessary and Proper Clause gives Congress the power to enact any law that might be connected to an ancillary power that is in turn somehow connected to an enumerated power, even if the challenged law does not actually do anything to enforce any enumerated power."49

This predicament gets at the second puzzle of the Comstock majority opinion: if not a requirement of a direct connection between legislated means and enumerated end, what exactly is a "rational" means-end fit under the Necessary and Proper Clause? This question is not a new one-it is simmering below the surface in cases from McCulloch through Greenwood and Sabri-but it is one that has never been fully answered. And, having deeper roots than the single Comstock opinion, it is a puzzle that (unlike the five factors puzzle) cannot be

direct link between the — the crime which brought you into Federal custody and your subsequent commitment.").

45130 S. Ct. at 1963 (quoting United States v. Lopez, 514 U.S. 549, 567 (1995)).

46350 U.S. 366 (1956) (upholding a statute evidently more than one-step removed from the constitutional power to "establish post offices and post roads"); see also $130 \mathrm{~S}$. Ct. at 1963.

${ }^{47} 541$ U.S. 600 (2004). In this case, the Court upheld the constitutionality of a statute making it a federal crime to bribe officials of non-federal organizations distributing federal funds, which was based on a power seemingly more than one step removed from the Spending Clause. See id. at 604-07; see also Comstock, 130 S. Ct. at 1964. The Sabri Court indicated that "means-end rationality" in the relationship between the legislation and the Spending Clause was sufficient under the Necessary and Proper Clause. 541 U.S. at 605.

${ }^{48}$ Comstock, 130 S. Ct. at 1956 ("[I]n determining whether the Necessary and Proper Clause grants Congress the legislative authority to enact a particular federal statute, we look to see whether the statute constitutes a means that is rationally related to the implementation of a constitutionally enumerated power.").

${ }^{49}$ Somin, supra note 5, at 253; see also id. at 254 ("In sum, under the majority's reasoning in Comstock, Congress would have almost as much authority as it currently has even if the Constitution gave Congress only two enumerated powers: the power to regulate interstate commerce and the Necessary and Proper Clause itself.”). 
addressed simply by looking to external indicators of Justice Breyer's jurisprudential approach. Much of the remainder of this paper will therefore be devoted to solving this deeper puzzle.

\section{B. Two Concurrences}

While Justice Breyer's conclusion in Comstock garnered seven of the nine Justices' votes, Justices Kennedy and Alito each concurred only in the judgment, and questioned aspects of Breyer's reinterpretation of the Necessary and Proper Clause.

Justice Alito explained that he was "concerned about the breath of the Court's language, and the ambiguity of the standard that the Court applies," though he "was persuaded, on narrow grounds, that it was 'necessary and proper' for Congress to enact the statute at issue in this case . . . in order to "carry into Execution' powers specifically conferred on Congress by the Constitution."50 In Alito's view, § 4248 carries into execution "the enumerated powers that support the federal criminal statutes under which the affected prisoners were convicted." Perhaps most noteworthy about this explanation is that Justice Alito seems to embrace the majority's assumption that the Necessary and Proper Clause does not require a one-step limit to the separation between an enumerated power and a “necessary and proper” exercise of Congress’ legislative power. Instead, § 4248 can be necessary to the federal criminal statutes that are, in turn, necessary and proper to Congress' enumerated powers. ${ }^{52}$ What is required, and what is present for $\S 4248$, Alito suggests, is simply "an 'appropriate' link between a power conferred by the Constitution and the law enacted by Congress.",53

Agreeing with the majority’s basic conclusion, Justice Kennedy concurred separately to note that the majority's "rational basis” necessary and proper test "must be employed with care." "54 Kennedy wished to assure the test in this context was not confused with the distinct (and less exacting) rational basis test applied, for instance, in the due process context, and that the test was applied with due regard for federalism principles. ${ }^{55}$

${ }^{50}$ Comstock, 130 S. Ct. at 1968-69 (Alito, J., concurring in the judgment) (internal citations omitted).

${ }^{51} \mathrm{Id}$. at 1969.

${ }^{52}$ See id. ("In other words, most federal criminal statutes rest upon a congressional judgment that, in order to execute one or more of the powers conferred on Congress, it is necessary and proper to criminalize certain conduct, and in order to do that it is obviously necessary and proper to provide for the operation of a federal criminal justice system and a federal prison system.”).

${ }^{53}$ Id. at 1970.

${ }^{54} \mathrm{Id}$.

${ }^{55} \mathrm{Id}$. at $1966-68$. 
But Justice Kennedy was even more explicit in his concurrence than Justice Alito that the Necessary and Proper Clause does not require a one-step link between an enumerated power and a given legislative act. "Respondents argue that congressional authority under the Necessary and Proper Clause can be no more than one step removed from an enumerated power. This is incorrect." As Kennedy explains, "[w]hen the inquiry is whether a federal law has sufficient links to an enumerated power to be within the scope of federal authority, the analysis depends not on the number of links in the congressional-power chain but on the strength of the chain., ${ }^{57}$ Thus, at least seven Justices agreed on some form of flexible-though not unconstrained-rational-basis-type necessary and proper standard.

\section{Thomas' Dissent}

That leaves two Justices who dissented from the majority's Comstock result. Justice Thomas wrote the dissent, and Justice Scalia joined most of it, but, notably, chose not to join the section in which Justice Thomas questioned the majority's rational basis approach to the Necessary and Proper Clause and argued that "the Clause plainly requires a showing that every federal statute 'carries into Execution' one or more of the Federal Government's enumerated powers." While Justice Scalia did not write separately to clarify his concerns, his unwillingness to join the section of Justice Thomas' opinion requiring a rigorously direct connection between an enumerated power and a given congressional act suggests that, like all the Justices in the majority, he too recognized flexibility in Congress' authority under the Necessary and Proper Clause.

Where Justice Scalia and Justice Thomas did agree was, first, that § 4248 went too far. Second, the two agreed on a concern shared, at least to some substantial degree, by Justices Alito and Kennedy, that the novelty and ambiguity of Justice Breyer's five considerations - the first puzzle of Comstock-was bound to cause problems. Thomas argued that "[t]he Court's newly minted test cannot be reconciled with the Clause's plain text or with two centuries of our precedent interpreting it." ${ }^{\text {59 }}$ Moreover, Thomas highlighted the amorphousness of the considerations:

Must each of the five considerations exist before the Court sustains future

${ }^{56} I d$. at 1965-66 (Kennedy, J., concurring in the judgment).

${ }^{57}$ Id. at 1966 .

${ }^{58}$ Id. at 1976 (Thomas, J., dissenting).

${ }^{59}$ Id. at $1974-75$. 
federal legislation as proper exercises of Congress’ Necessary and Proper Clause authority? What if the facts of a given case support a finding of only four considerations? Or three? And if three or four will suffice, which three or four are imperative? The Court provides no answers to these questions. ${ }^{60}$

Justice Thomas' worry has already proved prescient as lower courts struggling to apply the Comstock approach in other cases have faced substantial confusion. The following Part will explore this emerging confusion, which makes greater clarity as to the future of the Necessary and Proper Clause crucial.

\section{The Necessary ANd Proper Clause in DisarRay}

The many unanswered questions left in the Comstock majority's approach, particularly as to the application of the opinion's five considerations, have baffled lower courts attempting to move forward in interpreting the Necessary and Proper Clause's limits, both in cases related to Comstock, and cases in entirely different substantive areas of law. Among the most notable of these post-Comstock cases are those on the constitutionality of the PPACA. Most troublingly, in some of these cases, courts seem to be capitalizing on Comstock's ambiguities-whether intentionally or not-to interpret the scope of the Necessary and Proper Clause to meet their own needs, at times contributing to inconsistent outcomes across cases.

\section{A. Sex Offender Cases and Beyond}

Because cases requiring courts to rule on the constitutionality of congressional statutes are rare, there have been few lower court decisions applying Comstock to date; ${ }^{61}$ but those that have are cause for some concern.

\footnotetext{
${ }^{60} I d$. at 1975.

${ }^{61}$ Aside from the SORNA cases discussed at length in this Section and the health care law cases discussed in the following Section, another lower court case that applied Comstock in some detail is United States v. Belfast, 611 F.3d 783, 804, 808 (11th Cir. 2010) (upholding the constitutionality under the Necessary and Proper Clause of the Torture Act, 18 U.S.C. § 23402340A (2006), which implements the Convention Against Torture and Other Cruel, Inhuman or Degrading Treatment or Punishment, Dec. 10, 1984, 1465 U.N.T.S. 85); see also id. at 805 ("Congressional power to pass those laws that are necessary and proper to effectuate the enumerated powers of the Constitution is nowhere broader and more important than in the realm of foreign relations.”). There have not yet been any Supreme Court decisions applying the Comstock approach, though Justice Kennedy's concurrence was cited by Justice Stevens in his
} 
Cases interpreting a different provision of the same statute at issue in Comstock, the Sex Offender Registration and Notification Act (SORNA) (i.e., Title I of the Adam Walsh Act), ${ }^{62}$ provide a good example.

In United States v. Kebodeaux, the Fifth Circuit panel upheld the constitutionality of the SORNA provision enforcing the requirement that federal sex offenders register intrastate relocation. ${ }^{63}$ The Kebodeaux court listed all five of Comstock's factors, and asserted that "[t]hese factors implement the notion that Congress may pass laws rationally related or reasonably adapted to the effectuation of enumerated powers." ${ }^{, 64}$ Then, with virtually no analysis, the court held that, "[r]eviewing the Comstock factors in light of the Court's analysis, we conclude that the SORNA registration requirement for registration of federal sex offenders is rationally related to the original goals of the criminal statutes under which persons such as Kebodeaux were convicted.,65

Judge Dennis concurred in a separate opinion, in which he faulted the majority for its misapplication of Comstock. ${ }^{66}$ Judge Dennis explained: "I believe that the majority has fallen into serious error in reading Comstock to arrogate vast revisionary powers to judges, allowing them to uphold as necessary and proper any piece of legislation, regardless of the vehicle by which Congress enacted it, so long as the judges can in retrospect see a rational relationship between that law and some enumerated power."

Given the disagreement between the majority and Judge Dennis's concurrence, the Fifth Circuit panel agreed to rehear the case and issued a new opinion. ${ }^{68}$ This time the majority:

[Noted] at the outset that [Comstock's] 'considerations' are not factors to be balanced or that may cut for or against the constitutionality of a statute but rather an articulation of every reason supporting the Court's conclusion that the civil commitment at issue in Comstock was constitutional. Comstock does not require that every one of these considerations be present in every case, nor does Comstock in any respect

dissent in McDonald v. City of Chicago, 561 U.S. 3025, 3093 (2010) (Stevens, J., dissenting) ("The Constitution ... still allocates a general 'police power ... to the States and the States alone ....'” (citing Comstock, 130 S. Ct. at 1967 (Kennedy, J., concurring in the judgment)).

${ }^{62}$ Pub. L. 109-248, 120 Stat. 587 (2006).

${ }^{63} 634$ F.3d 293, 294 (5th Cir. 2011) (upholding 18 U.S.C. § 2250(a)(2)(A)), superceded by 647

F.3d 137 (5th Cir 2011), reh'g en banc granted, 647 F.3d 605 (5th Cir. 2011)

${ }^{64} 634$ F.3d at 297.

${ }^{65} \mathrm{Id}$. at 298.

${ }^{66} \mathrm{Id}$. at 304-05 (Dennis, J., concurring).

${ }^{67} \mathrm{Id}$. at 304-05.

${ }^{68}$ United States v. Kebodeaux, 647 F.3d 137 (5th Cir. 2011). 
purport to overrule the Court's prior decisional law. ${ }^{69}$

The court nevertheless went on to show how the Comstock considerations weighed in favor of upholding the provision at issue in Kebodeaux. ${ }^{70}$ Judge Dennis, meanwhile, maintained his separate opinion, ${ }^{71}$ and, with the continued disagreement and confusion, the Fifth Circuit recently agreed to rehear the case en banc. $^{72}$

Like Judge Dennis, the majority in a Tenth Circuit case ruling on the constitutionality of the SORNA provision at issue in Kebodeaux also applied Comstock differently than the Kebodeaux majority. In United States $v$. Yelloweagle, the Tenth Circuit, like the Fifth Circuit, upheld the constitutionality of the SORNA registration enforcement provision under the Necessary and Proper Clause. ${ }^{73}$ But the Yelloweagle court did not consider any of the five Comstock factors explicitly. ${ }^{74}$ Instead, the court simply noted that Comstock required that congressional statutes "constitute a means that is rationally related to the implementation of a constitutionally enumerated power," in order to be "necessary and proper."75 It then held that the SORNA provision at issue constituted such a means because "[i]t seems beyond peradventure that the criminal enforcement provision of $\S 2250(a)(2)(A)$ is 'rationally related or reasonably adapted to the effectuation' of the sex offender registration regime,"”6 in turn a proper exercise of Congress' Commerce Clause power. ${ }^{77}$

While the two circuits that have addressed the constitutionality of this SORNA provision under the Necessary and Proper Clause so far came to the same conclusion, despite their differing applications of Comstock's amorphous considerations, the lower courts applying Comstock in the critically important PPACA context have had less consistent outcomes.

\footnotetext{
${ }^{69}$ Id. at 142 .

${ }^{70}$ See id. at $142-46$.

${ }^{71} \mathrm{Id}$. at $146-56$.

${ }^{72}$ United States v. Kebodeaux, 647 F.3d 605 (5th Cir. 2011) (granting rehearing en banc).

${ }^{73} 643$ F.3d 1275, 1277 (10th Cir. 2011).

${ }^{74}$ A different Tenth Circuit panel has since noted its interpretation that: "[a]lthough the Court referenced these considerations, it did not suggest that they should be balanced or considered in every Necessary and Proper Clause analysis. Rather, the five considerations appear to be an articulation of the reasons that supported the Court's conclusion that the statute at issue was constitutional.” United States v. Carel, No. 10-1095, slip op. at 19 n.8 (10th Cir. Dec. 30, 2011) (citations omitted).

${ }^{75} 643$ F.3d at 1285.

${ }^{76}$ Id. at 1288 (quoting United States v. Kebodeaux, 634 F.3d 293, 297 (5th Cir. 2011)).

${ }^{77}$ See Yelloweagle, 643 F.3d at 1286.
} 


\section{B. The Affordable Care Act Cases}

The U.S. Supreme Court granted certiorari in November 2011 to settle the inconsistent decisions in the lower courts on the constitutionality of the PPACA, and particularly its so-called individual mandate, imposing a fee for failure to purchase health insurance. Four courts of appeals have heard cases on the constitutionality of the mandate, with the Sixth ${ }^{78}$ and D.C. Circuits ${ }^{79}$ upholding the mandate on the merits, the Eleventh Circuit finding it unconstitutional (but also severable from the constitutional act as a whole), ${ }^{80}$ and the Fourth Circuit finding two separate challenges to be jurisdictionally barred. ${ }^{81}$

Some of these decisions, and the district court decisions on the same question, considered whether the individual mandate is "necessary and proper" at some length, often discussing Comstock. Some focused on other grounds for their decisions, like the Commerce Clause, ${ }^{82}$ the Taxing Clause, or jurisdictional bars, and largely or entirely avoided explicit reference to the Necessary and Proper Clause. What is clear in the decisions is that those finding the mandate unconstitutional have tended to spend substantial energy distinguishing Comstock, ${ }^{83}$ while the other cases, including those upholding the mandate, have tended to bypass the necessary and proper issue. ${ }^{84}$

\footnotetext{
${ }^{78}$ Thomas More Law Center v. Obama, 651 F.3d 529 (6th Cir. 2011).

${ }^{79}$ Seven-Sky v. Holder, No. 11-5047, 2011 WL 5378319 (D.C. Cir. Nov. 8, 2011).

${ }^{80}$ Florida v. U.S. Dep’t of Health \& Human Servs., 648 F.3d 1235 (11th Cir. 2011), cert granted, 80 U.S.LW. 3198 (U.S. Nov. 14, 2011) (No. 11-393), 80 U.S.L.W 3199 (U.S. Nov. 14, 2011) (No. 11-398), cert, granted in part, 2011 WL 5515165 (U.S. Nov. 14, 2011) (No. 11-400).

${ }^{81}$ Liberty University v. Geithner, No. 10-2347, 2011 WL 3962915 (4th Cir. Sept. 8, 2011) (vacating and remanding with instructions to dismiss for lack of jurisdiction, as a result of the Anti-Injunction Act, 28 U.S.C. § 2283 (2006)); Virginia ex rel. Cuccinelli v. Sebelius, 653 F.3d 253 (4th Cir. 2011) (vacating and remanding with instructions to dismiss for lack of standing).

${ }^{82}$ It is worth noting that Commerce Clause jurisprudence often conflates Necessary and Proper Clause analysis, particularly because the "substantial effects" test under the Commerce Clause is in at least some sense a test of how necessary and proper a given legislative act is to the Commerce Power. See, e.g., Gonzales v. Raich, 545 U.S. 1, 34 (2005) (Scalia, J., concurring) ("Congress's regulatory authority over intrastate activities that are not themselves part of interstate commerce (including activities that have a substantial effect on interstate commerce) derives from the Necessary and Proper Clause.").

${ }^{83}$ See Florida, 648 F.3d 1235, at 1279-82, 1302-04 (11th Cir. 2011); Florida ex rel. Bondi v. U.S. Dep't of Health \& Human Servs., 780 F. Supp. 2d 1256, 1295-97 (N.D. Fla. 2011), aff'd in part, rev'd in part sub nom. Florida v. U.S. Dep't of Health \& Human Servs, 648 F.3d 1235 (11th Cir. 2011); Virginia ex rel. Cuccinelli v. Sebelius, 728 F. Supp. 2d 768, 778-82 (E.D. Va. 2010), vacated on other grounds, 656 F.3d 253 (4th Cir. 2011).

${ }^{84}$ See Seven-Sky v. Holder, No. 11-5047, 2011 WL 5378319, at *2, 9 (D.C. Cir. Nov. 8, 2011) (failing to cite Comstock or provide any extended analysis of the Necessary and Proper Clause); Liberty University v. Geithner, No. 10-2347, 2011 WL 3962915, at *45 (4th Cir. Sept. 8, 2011) (failing to mention Comstock or the Necessary and Proper Clause, except in passing in Judge Davis’ dissent); Virginia ex rel. Cuccinelli v. Sebelius, 653 F.3d 253 (4th Cir. 2011) (failing to
} 
In the Eleventh Circuit, for example, the majority, which struck down the individual mandate, noted that the Comstock "majority opinion enumerated five 'considerations' that supported the statute's constitutional validity," and proceeded to discuss how all five were met in Comstock. ${ }^{85}$ The Eleventh Circuit presented these factors as a kind of test, and later suggested that failure to satisfy all the factors put the constitutionality of the individual mandate in doubt. ${ }^{86}$ The court focused on the fact that the individual mandate was a subject of traditional state concern, implicating "three of the five Comstock factors pertinent to a Necessary and Proper Clause analysis: (1) whether there is a long history of federal involvement in this arena, (2) whether the statute accommodates or supplants state interests, and (3) the statute's narrow scope."87

The district court opinion in the case also applied Comstock's factors. The court explained:

To the extent that [the factors] constitute a 'test,' the individual mandate clearly gets a failing score on at least two (and possibly a couple more) of the five elements. A statute mandating that everyone purchase a product from a private company or be penalized . . . is not a 'modest' addition to federal involvement in the national health care market, nor is it 'narrow [in] scope. ${ }^{88}$

mention Comstock or the Necessary and Proper Clause at all); Thomas More Law Center v. Obama, 651 F.3d 529, 554, 564, 570 n.2 (6th Cir. 2011) (citing Comstock only in passing in Judge Sutton's concurrence, and the Necessary and Proper Clause only in passing in the majority opinion and in a footnote in Judge Graham's concurrence); Liberty University v. Geithner, 753 F. Supp. 2d 611, 630 (W.D. Va. 2010) ("Because I find that the employer and individual coverage provisions are within Congress' authority under the Commerce Clause, it is unnecessary to consider whether the provisions would be constitutional exercises of power pursuant to . . . the Necessary and Proper Clause.”), vacated on other grounds, 656 F.3d 253; Thomas More Law Center v. Obama, 720 F. Supp. 2d 882 (E.D. Mich. 2010) (failing to mention Comstock or the Necessary and Proper Clause), aff'd, 651 F.3d 529. But see Mead v. Holder, 766 F. Supp. 2d 16, 34-35 (D.D.C. 2011) (discussing the Necessary and Proper Clause, including Comstock, at some length, and holding that the individual mandate did not contravene the Necessary and Proper Clause), aff'd, sub nom. Seven-Sky v. Holder, 2011 WL 5378319.

${ }^{85}$ Florida, 648 F.3d at 1279-82.

${ }^{86}$ See id. at 1306 ("[I]t is undisputed that the individual mandate supersedes a multitude of the states' policy choices in these key areas of traditional state concern. Congress's encroachment upon these areas of traditional state concern is yet another factor that weighs in the plaintiffs' favor, and strengthens the inference that the individual mandate exceeds constitutional boundaries.”).

${ }^{87} \mathrm{Id}$. at 1304 .

${ }^{88}$ Florida ex rel. Bondi, 780 F. Supp. 2d at 1295. 
The court went on to assume "that the Comstock 'considerations' were just that," i.e., considerations and not a test per se, ${ }^{89}$ but used the considerations to find in the end that the individual mandate "cannot be reconciled with a limited government of enumerated powers" and thus was unconstitutional under the Necessary and Proper Clause. ${ }^{90}$

Judge Marcus' dissent in the Eleventh Circuit took a different approach. Instead of emphasizing the ambiguity of the Comstock "test," and the factors on which the individual mandate might rest on shaky ground, Judge Marcus discussed Comstock only in the context of affirming means-ends rationality as the one critical test of constitutionality under the Necessary and Proper Clause, and underlining the "expansive definition of "necessary"” reiterated in Comstock. ${ }^{1}$ Similarly, the lower court majority opinions upholding the individual mandate also have tended to emphasize only Comstock's rational basis test, rather than the five factors, to the extent they consider the case, and Necessary and Proper Clause analysis, at all. ${ }^{92}$

In some sense, it may seem counterintuitive that the opinions upholding the individual mandate have tended to avoid the Comstock considerations, while those finding the mandate unconstitutional have relied on them heavily. After all, Justice Breyer used the considerations to uphold the civil commitment provision at issue in Comstock, and his generally deferential and pragmatic approach suggests he meant for the considerations to be used flexibly. ${ }^{93}$ But because the way the Comstock factors are to be applied, and whether they ultimately make the McCulloch test more or less stringent, is not entirely evident from the opinion itself, courts looking to uphold a provision like the individual mandate that may rest on shaky ground with respect to at least some of the Comstock factors, ${ }^{94}$

${ }^{89} \mathrm{Id}$.

${ }^{90} \mathrm{Id}$. at 1298.

91 Florida, 648 F.3d at 1349 (Marcus, J., concurring in part and dissenting in part) (“"[T]he relevant inquiry is simply whether the means chosen are reasonably adapted to the attainment of a legitimate end under the commerce power ... .' And the mandate is undoubtedly 'rationally related' to the end of effectuating the Act's guaranteed issue and community rating reforms." (quoting United States v. Comstock, 130 S. Ct. 1949, 1956 (2010))).

92 See, e.g., Thomas More Law Center v. Obama, 651 F.3d 529, 564 (6th Cir. 2011) (Sutton, J., concurring) ("The courts . . . require only an 'appropriate' or 'reasonable' 'fit' between means and ends.” (citing United States v. Comstock, 130 S. Ct. 1949, 1956-57 (2010))); see also supra note 84 and accompanying text. It is worth noting that the D.C. district court opinion upholding the individual mandate, which considered Comstock in significantly more detail than other decisions upholding the mandate, still did not discuss the five factors. See Mead v. Holder, 766 F. Supp. 2d 16, 34-35 (D.D.C. 2011).

${ }^{93}$ See supra Subsection II.a.ii.

${ }^{94}$ See supra notes 85-88 and accompanying text; see also Shapiro \& Burris, supra note 5, at 42324 ("Looking at the five considerations offered by the Comstock majority, it is not at all clear that the case favors the government's defense of Obamacare. . . . [T] fhe first factor is essentially 
might well avoid relying on these factors, and instead focus on, for instance, the opinion's looser rational basis test. (And so they have. ${ }^{95}$ ) Meanwhile, courts looking to strike down a provision like the individual mandate might well draw heavily on the factors as constraints. (And so they have, too.)

In short, the lower courts, whether knowingly or not, seem to be exploiting Comstock's uncertainties to meet their own needs. Thus, the opinion's ambiguities are contributing to inconsistent interpretations across the lower courts. And they will likely continue to do so with respect to the constitutionality of future federal laws until the scope of the Necessary and Proper Clause after Comstock finally becomes clear.

\section{Fixing the Necessary and Proper Clause After Comstock}

In order to bring clarity to the Necessary and Proper Clause after Comstock, this Part first returns to history. It draws on new research on the origins and structure of the Clause in fiduciary and agency law to consider what

irrelevant; while Comstock and other cases have already established that Congress's powers under the Necessary and Proper Clause are broad, whether they are so broad as to encompass the individual mandate is the very question at issue. Comstock's second consideration-a history of federal regulation in the area-does not clearly weigh to either side. . . . The third factorwhether Congress had 'sound reasons' for enacting the mandate-is at the very least debatable. ... . Factors four and five-the accommodation of state interests and the narrow scope of the law-are also exceedingly difficult for Obamacare to satisfy.” (internal citations omitted)).

${ }^{95}$ Interestingly, the Obama Administration — perhaps fearing that the factors could be read against them-also has not relied on the Comstock considerations in its briefing in support of the PPACA, though it has cited in passing to other, more obviously deferential statements from Comstock. See, e.g., Brief for Respondent, Virginia ex rel. Cuccinelli v. Sebelius, No. 11-420, petition for cert. filed Sept. 30, 2011 (avoiding any citation to Comstock); Petition for a Writ of Certiorari at 14, 16, Dep’t of Health \& Human Servs. v. Florida, No. 11-398 (filed Sept. 28, 2011) (citing Comstock only for the propositions that "the Constitution's grants of specific federal legislative authority are accompanied by broad power to enact laws that are 'convenient, or useful' or 'conducive' to the authority's 'beneficial exercise'” and that the choice of rational means for carrying out an enumerated end is left primarily to Congress); Brief for Respondents, Thomas More Law Center v. Obama, No. 11-117, petition for cert. filed July 26, 2011 (citing Comstock only for its assertion that the Necessary and Proper Clause grants "broad power to enact laws that are 'convenient, or useful' or 'conducive' to the authority's 'beneficial exercise"” and that there is a "'presumption of constitutionality' . . ' 'when examining the scope of Congressional power”'); see also Shapiro \& Burris, supra note 5, at 422 ("[T]he government has been citing Comstock in its briefs defending the legislation against legal challenge. It is initially telling, however, that the case has merited little more than a passing mention in this briefing. Comstock is simply not a case that the government is hanging its hat on ....”). This may be part of the reason the courts in which the Administration has won the day have not themselves relied heavily on Comstock. 
"necessary and proper" meant to the Framers, as well as John Marshall in McCulloch, and what it should be understood to mean moving forward.

The remainder of this Part uses the history, and the earlier analysis of Comstock and the confusion it has engendered, to evaluate three possible readings of the Necessary and Proper Clause after Comstock. On the side of more aggressive judicial enforcement might be a "rational basis with bite"-type test, while, on the other end of the spectrum, Comstock might be read to move toward abandonment of the field of judicial enforcement of the Necessary and Proper Clause. Yet, this Article will ultimately argue that an intermediate position, closely tailored to the history laid out in this Part-a modern fiduciary theory of the Necessary and Proper Clause-is the most natural reading of the Clause after Comstock.

\section{A. Back to Basics: History of the Clause}

Perhaps in substantial part because the jurisprudence around the Clause was long viewed as settled, the Necessary and Proper Clause has not been the subject of copious historical analysis. The Clause, which was the subject of virtually no (recorded) discussion at the Philadelphia Convention, ${ }^{96}$ was labeled by one constitutional scholar "a masterpiece of enigmatic formulations,"97 and was long considered, for the most part, a "mystery."98 But Gary Lawson, Geoffrey Miller, Robert Natelson, and Guy Seidman recently published a volume arguing that there may be another good reason so little was known about the Necessary and Proper Clause before: historians were looking in all the wrong places. ${ }^{99}$ Rather than in the debates among the Framers, the real roots of the Clause lie deeper, in background principles of agency, administrative, and corporate law that "infused" the Framers worldviews, but are not typically looked to by constitutional scholars or judges. ${ }^{100}$

This Section explores this latest research on the origins of the Clause, but with an eye toward a goal Lawson and his co-authors have explicitly avoided ${ }^{101}$ :

${ }^{96}$ See Randy E. Barnett, The Original Meaning of the Necessary and Proper Clause, 6 U. PA. J. CONST. L. 183, 185 (2003).

${ }^{97}$ Mark A. Graber, Unnecessary and Unintelligible, 12 CONST. COMmENTARY 167, 168 (1995).

${ }^{98}$ LAWSON ET AL., supra note 6, at 2.

${ }^{99} \mathrm{Id}$. at 5.

${ }^{100} \mathrm{Id}$.

${ }^{101}$ Id. at 8 ("There is enough convergence to permit reasonably confident assertions about the clause's actual origins. An obvious next question is whether there is enough convergence to support a general theory of the clause's actual meaning. Although that may be an obvious next question, it is not one this book seeks to pursue. . . . We fervently wish to elide those kinds of broad issues in this book -if only because the authors do not necessarily agree about interpretive methodology.”). 
applying the history to move toward a general theory of the meaning of the Clause, particularly in the wake of Comstock.

\section{Roots in Fiduciary and Agency Law}

Chief Justice Marshall famously exhorted in McCulloch: "we must never forget that it is a constitution we are expounding."102 The claim, like the Necessary and Proper Clause itself, might seem—in some sense-enigmatic: we must never forget it is a constitution ... a as opposed to what? But recent research suggests an obvious contrast: a corporate charter, a small-scale, Constitution-like document that would have been eminently familiar to Marshall and the rest of the Framers. ${ }^{103}$

In the eighteenth and early nineteenth centuries, when corporations were quasi-public entities performing largely public tasks, corporate charters tended to define specific powers and responsibilities, rather than offering general authorization to do business. ${ }^{104}$ Geoffrey Miller's extensive study of these charters has demonstrated that terms like "necessary," "proper," and "necessary and proper" were commonplace in the charters. ${ }^{105}$ And their use often paralleled the use of the terms in the Constitution, to allow for extension of enumerated rules, ${ }^{106}$ while limiting the discretion of the corporate officers to actions needed to carry out those rules. ${ }^{107}$ The terms used to describe the granted scope of authority varied, but "necessary" and "proper" were the most common, and doublets like "necessary and proper" were also typical. ${ }^{108}$ Miller argues that such doublets could be read as redundant, since necessary exercises of authority would seem to

\footnotetext{
${ }^{102}$ McCulloch v. Maryland, 17 U.S. (4 Wheat.) 316, 407 (1819).

${ }^{103}$ See Geoffrey P. Miller, The Corporate Law Background of the Necessary and Proper Clause, in LAWSON ET AL., supra note 6, at 144, 175.

${ }^{104}$ LAWSON ET AL., supra note 6, at 7.

${ }^{105}$ Miller, supra note 103, at 145.

${ }^{106} \mathrm{Id}$.

${ }^{107}$ Id. at 150.

${ }^{108}$ Id. at 152-54. Among other common scope terms seen in the charters studied by Miller were "expedient," "fit," "convenient," "at pleasure," and "appertaining," while other common doublets included "expedient and necessary," "fit and expedient," "necessary and convenient," "fit and proper," "suitable and necessary," and "necessary or convenient." Id. Interestingly, the doublets consistently included both a term suggesting firm limits to a grant of authority, like "necessary," and maybe "fit" (though Samuel Johnson's dictionary listed "fit" as a synonym of proper, see 2 SAMUEL JOHNSON, DiCTIONARY OF THE ENGLISH LANGUAGE (1785)); and a term suggesting more discretionary appropriateness limits like "proper," "expedient," "suitable," and "convenient." See also Robert G. Natelson, The Legal Origins of the Necessary and Proper Clause, in LAWSON ET AL., supra note 6, at 68-80 (describing five "formulas" of necessary and proper-like constructions in eighteenth century documents conveying authority).
} 
be a subset of proper ones. ${ }^{109}$ But he concludes that, while "necessary" suggests the need for a fit between ends enumerated in the charter and means chosen to carry them out, "proper” might have expressed separately, at least rhetorically, the idea that officers should act "so as to consider the effect on stakeholders in the firm.” "110 As applied to the Constitution's Necessary and Proper Clause, this may suggest that the Clause should be read to require both means-ends fit and consideration of propriety of lawmaking for individual citizens. ${ }^{111}$

This conclusion is broadly consistent with the independent conclusions of Robert Natelson, studying the "necessary and proper" concept in the eighteenth century private law of agency, ${ }^{112}$ and Gary Lawson and Guy Seidman, studying the pre-constitutional British and colonial administrative law background. ${ }^{113}$ Together, all three lines of research point to what they call "public agency law" roots for the Necessary and Proper Clause, linked to fiduciary principles. ${ }^{114}$

Lawson and Seidman focus on the administrative law principle of "reasonableness"—or, as it might also, perhaps more precisely, be termed, "the principle of fiduciary public agency" - in British and colonial administrative law. ${ }^{115}$ That principle, which was well established by the eighteenth century and would therefore have been very familiar to the Framers (many of whom were, of course, lawyers ${ }^{116}$ ), requires delegations of authority "to be exercised with impartiality, efficacy, proportionality, and regard for people's rights."117 The "necessary and proper" construction, in turn, explicitly codifies these very principles. "Necessary" reflects efficacy and proportionality limits; while "proper" suggests impartiality, regard for rights, and fiduciary principles broadly. ${ }^{119}$

\footnotetext{
${ }^{109}$ Miller, supra note 103, at 159.

${ }^{110} \mathrm{Id}$. at $174-75$.

111 See id.

112 This work was first published in Robert G. Natelson, The Agency Law Origins of the Necessary and Proper Clause, 55 CASE W. RES. L. REV. 243 (2004), and adapted and expanded upon in chapters 4 and 5 of LAWSON ET AL., supra note 6.

113 They began this project in GARY LAWSON \& GUY SEIDMAN, THE CONSTITUTION OF EMPIRE: TERRITORIAL EXPANSION AND AMERICAN LEGAL HistORY 51-57 (2004), and applied it at length to the Necessary and Proper Clause in chapters 2, 3, and 6 of LAWSON ET AL., supra note 6.

${ }^{114}$ LAWSON ET AL., supra note 6, at 6.

115 Gary Lawson and Guy I. Seidman, Necessity, Propriety, and Reasonableness, in LAWSON ET AL., supra note 6, at 120, 120-21.

116 Robert G. Natelson, The Framing and Adoption of the Necessary and Proper Clause, in LAWSON ET AL., supra note 6, at 84, 85 ("All [the Framers] were men of affairs, public and private, and a clear majority were, or had been, practicing lawyers. Seven of the fifty-five . . .had attended London's Inns of Court.”).

${ }^{117}$ Lawson \& Seidman, supra note 115, at 120-21.

${ }^{118}$ See id. at 141.

119 See id. at 142.
} 
These conclusions, in turn, "work hand in hand"120 with Natelson's private agency law conclusions. Even those Framers who were not lawyers were typically actively involved in business, and thus commonly employed, or served as, private fiduciaries, for instance in trading their crops. ${ }^{121}$ Moreover, fiduciary relationships were also common within families: prominent men in the eighteenth century frequently served as guardians, executors, administrators, and trustees. ${ }^{122}$ Thus the Framers were likely very familiar with fiduciary principles, including the duties of care, good faith, loyalty, and impartiality, which have not changed dramatically between the Framers' era and our own. ${ }^{123}$

In order to determine the reach of these fiduciary duties, the relevant principles at the time were those of "principal-and-incident" law, which governed the exercise of implied, incidental authority that came along with express fiduciary duties enumerated in an authorizing document. ${ }^{124}$ Common law cases contemporary to the constitutional convention, like Gardner v. Baillie ${ }^{125}$ and Howard v. Bailee, ${ }^{126}$ affirm the interpretation of "necessary and proper"-type clauses (in these cases, in a disputed letter of attorney) as grants of incidental authority to agents, e.g., to Ms. Bailee's accountant to administer her husband's estate, limited only by background fiduciary principles. Thus, here too, the same basic implications for the Constitution's Necessary and Proper Clause are clear: the Clause followed similar constructions from the time granting unenumerated powers to agents (whether estate administrators, or Congressmen) in order to execute the relevant enumerated powers, limited only by background fiduciary principles.

\section{Framers' Intent}

But what does the evidence from the Constitution's drafting, as well as the subsequent ratification and early congressional debates, suggest about the original meaning of the Necessary and Proper Clause? Especially when considered in

\footnotetext{
${ }^{120}$ Id. at 143.

${ }^{121}$ Natelson, supra note 108 , at 56.

${ }^{122}$ See id. ("There is reason to believe that people had significantly more exposure to that fiduciary service than is true today, both because the shorter life expectancy of the time left far more estates to administer per capita and because guardians and executors typically served in teams rather than singly. Certainly, general knowledge of the law was more widely spread than it is today, a one can see from the records of the public debates, very often carried on in explicitly legal terms.").

${ }^{123}$ Id. at 57-60; see also id. at 57 ("A full discussion of contemporaneous fiduciary duties is beyond the scope of this book, but in general they were similar to those imposed today.”).

${ }^{124}$ See id. at 60 .

125 (K.B. 1795) 6 T.R. 591, 101 Eng. Rep. 720.

${ }^{126}$ (K.B. 1796) 2 H. Bl. 618, 126 Eng. Rep. 737. For more on the Baillie cases, see Natelson, supra note 108 , at $80-82$.
} 
light of the background principles just discussed, they show the Framers attempting to enable Congress to act as reasonably needed to carry out its enumerated powers, and to do so as proper fiduciary agents of "the People" placed front and center in the Constitution's preamble.

The Committee of Detail's draft language for what would become the Necessary and Proper Clause first referred to a "right to make all Laws necessary to carry the foregoing Powers into Execu-."127 Edmund Randolph, a member of the Committee, later confirmed that this language applied the incidental powers doctrine, noting that " $[\mathrm{t}] \mathrm{o}$ be necessary is to be incidental, or, in other words, may be denominated the natural means of executing a power."128 The "and proper" language was added to the Necessary and Proper Clause afterward. Though there is no record of the reason, the separate addition does suggest the "proper" piece was more than boilerplate redundancy. ${ }^{129}$

Rather, the constitutional ratifying debates suggest that "proper"-and "necessary and proper” more broadly_meant to incorporate agency and fiduciary law limiting principles on the exercise of congressional power. The Virginia debates offer an especially rich record. In Virginia, as elsewhere, Antifederalists deemed the Necessary and Proper Clause the "Sweeping Clause," and stoked fears that it gave Congress unlimited power. ${ }^{130}$ The Constitution's supporters responded by noting that the Clause does not create new powers but only makes explicit the natural assumption-applying agency principles - that enumerating certain powers implies incidental powers to carry out the enumerated ones. ${ }^{131}$

1272 The Records of the Federal Convention of 1787, at 44 (Max Farrand, ed., rev. ed. 1937).

${ }^{128}$ Opinion of Edmund Randolph, Attorney General of the United States, to President Washington (Feb. 12, 1791), reprinted in LEGISLATIVE AND DOCUMENTARY HISTORY OF THE BANK OF THE United StAtes 86, 89 (Matthew St. Clair Clarke \& David A. Hall eds., Gales \& Seaton 1832); see also Opinion of Attorney General No. 2 (Feb. 12, 1791), reprinted in LEGISLATIVE AND DOCUMENTARY HISTORY OF THE BANK OF THE UNITED STATES 89, 90 ("If [the powers to incorporate a national bank] be incidental powers, and the conclusion be, that, because some incidental powers are expressed, no others are admissible, it would not only be contrary to the common forms of construction, but would reduce the present Congress to the feebleness of the old one, which could exercise no powers not expressly delegated.”).

129 Natelson, supra note 116 , at 89.

130 See id. at 94-96.

${ }^{131}$ See, e.g., An Impartial Citizen V, Petersburg VA. GAZETTE, Feb. 28, 1788, reprinted in 8 The DOCUMENTARY HiSTORY OF THE RATIFICATION OF THE CONSTITUTION 431 (John P. Kaminski \& Gaspare J. Saladino eds., 1988) (“Now, I insist that [Antifederalist] Mr. Mason’s construction on this clause is absolutely puerile .... When a power is vested anywhere, from the nature of things it must be understood to be attended by both other incidental powers as are necessary to give it efficacy; for so to say, that a power is given, without the power of enforcing it, is a solecism of language.”). For a view from outside Virginia, see THE FEDERALIST No. 33, at 221-22 (Alexander Hamilton) (Cynthia Brantley Johnson ed., 2004) ("[The Necessary and Proper Clause and the Supremacy Clause] have been the source of much virulent invective and petulant declamation 
Edmund Randolph (who refused to sign the Constitution in Philadelphia, but later supported its ratification in Virginia) explained: "The formidable clause does not in the least increase the powers of Congress. It is only inserted for greater caution." "32 Madison added: "[W]hat new terrors can arise from this particular clause? It is only a superfluity. . . . [I]t gives no supplementary power. It only enables [Congress] to execute the delegated powers. . . . For when any power is given, its delegation necessarily involves authority to make laws to execute it."133

Henry "Light Horse Harry" Lee invoked agency limitations explicitly: "[I]f a man delegated certain powers to an agent, it would be an insult upon common sense to suppose that the agent could legally transact any business for his principal which was not contained in the commission whereby the powers were delegated."134 Though Madison did not refer directly to agency law in his retorts to the Antifederalists, his adherence to an agency theory of the Necessary and Proper Clause - and government more generally - was made quite clear in the ratification debates. As he noted at one point: "[t]he members of the . . . government ... are the agents of, and subordinate to, the people."135

The flip-side of Madison and the Federalists' vision of the Necessary and Proper Clause is that, while the Clause permits only those laws necessary and proper to carry out enumerated powers, it thereby permits all laws that an agent would properly execute to carry out those powers, in light of background fiduciary principles. As Madison explained in The Federalist: "[n]o axiom is more clearly established in law, or in reason, than that wherever the end is required, the means are authorized; whenever a general power to do a thing is given, every particular power necessary for doing it, is included.”136

against the proposed Constitution. ... [A]nd yet, strange as it may appear, after all this clamor ... it may be affirmed with perfect confidence, that the constitutional operation of the intended government would be precisely the same, if these clauses were entirely obliterated, as if they were repeated in every article. They are only declaratory of a truth, which would have resulted by necessary and unavoidable implication from the very act of constituting a Federal Government, and vesting it with certain specific powers.”).

1323 The Debates in the Several State Conventions on the Adoption of the Federal Constitution 206 (Jonathan Elliot ed., 2d ed. 1891) [hereinafter ElLiOT’s DeBATES].

${ }^{133}$ Id. at 438; see also THE FEDERALIST No. 44, at 322 (James Madison) (Cynthia Brantley Johnson ed., 2004) ("Few parts of the Constitution have been assailed with more intemperance than [the Necessary and Proper Clause]; yet on a fair investigation of it, no part can appear more completely invulnerable. Without the substance of this power, the whole Constitution would be a dead letter.”).

1343 ELLIOT's DEBATES, supra note 132 at 186.

${ }^{135} \mathrm{Id}$. at 306.

136 The Federalist No. 44, at 324 (James Madison) (Cynthia Brantley Johnson ed., 2004); see also THE FederAlist No. 33, at 222 (Alexander Hamilton) ("What is a power, but the ability or faculty of doing a thing? What is the ability to do a thing but the power of employing the means necessary to its execution? What is a LEGISLATIVE power but a power of making LAWS? What are the means to execute a LEGISLATIVE power but LAWS?”). 
Moreover, in early congresses, this flip-side gained prominence, and the Necessary and Proper Clause came to be understood, at least by Federalists, as a provision granting Congress broad authority to act in the nation's best interests to carry out its enumerated powers. ${ }^{137}$ For some Federalists, having any precise link to an enumerated power was in fact unnecessary. Early legislation as important as assumption of the states' debt was passed at least in part by invocation of the Necessary and Proper Clause, but without an explicit link to an enumerated power. ${ }^{138}$ Madison reasserted the need for an explicit link to an enumerated power in the debates over the First National Bank ${ }^{139}$ and the more radical reading gradually disappeared after Jefferson and the Republicans came to power. ${ }^{140}$ What remained—as confirmed in the debate over the Second National Bank—was an understanding of the Necessary and Proper Clause that saw Congress as an empowered, if constitutionally limited, agent of the American people.

\section{B. McCulloch as Defining (But Incomplete) Interpretation}

Like Madison and many of the Framers, John Marshall saw government through the lens of the agency theory that was a fundamental legal background at the time. "It is the plain dictate of common sense, and the whole political system is founded on the idea," Marshall wrote, "that the departments of government are the agents of the nation, and will perform, within their respective spheres, the duties assigned to them." ${ }^{141}$ This elaboration of an agency theory of government, notably, came in the course of defending Marshall's decision in McCulloch v. Maryland, in which the Chief Justice upheld Congress' power under the Necessary and Proper Clause to incorporate the Second National Bank. ${ }^{142}$

McCulloch drew explicitly on the incidental powers theory from agency law. This may seem natural given that McCulloch's counsel, the distinguished advocate and former U.S. Attorney General, minister to Russia, and U.S. Senator

\footnotetext{
${ }^{137}$ Cf. Joseph M. Lynch, United States v. Comstock and the Necessary and Proper Clause: A Concurring, Albeit Unsettling, Opinion 10-18 (Sept. 2011) (unpublished manuscript).

${ }^{138}$ See id. at 12. But cf. Natelson, supra note 116, at 115-18 (arguing that there was broad agreement on the principles underlying the Necessary and Proper Clause, and particularly some variation of the incidental powers doctrine, by the time of the congressional debates on the First National Bank in 1791).

13914 Documentary History of the First Federal Congress 367, 371 (Linda Grant Depauw et al. eds. 1972) (statement of Rep. Madison) ("Its meaning must, according to the natural and obvious force of the terms and the context, be limited to means necessary to the end, and incident to the nature of the specified powers."); see also Lynch, supra note 137, at 13.

${ }^{140}$ See id. at 17.

${ }^{141}$ John Marshall, A Friend of the Constitution, AlEXANDRIa GAZETTE, July 15, 1819, reprinted in JoHn MARSHALL'S DEFENSE OF MCCULLOCH V. MARYLAND 211 (Gerald Gunther ed. 1969).

14217 U.S. (4 Wheat.) 316, 424 (1819).
} 
(among other things), William Pinkney, relied heavily on the theory in his argument, ${ }^{143}$ noting for instance that " $[\mathrm{t}]$ he power of erecting corporations is not an end of any government; it is a necessary means of accomplishing the ends of all governments. It is an authority inherent in, and incident to, all sovereignty."144 Marshall himself explained: "Among the enumerated powers, we do not find that of establishing a bank or creating a corporation. But there is no phrase in the instrument which, like the articles of confederation, excludes incidental or implied powers; and which requires that everything granted shall be expressly and minutely described."145 Rather, Marshall continued: “a government, intrusted with such ample powers, on the due execution of which the happiness and prosperity of the nation so vitally depends, must also be intrusted with ample means for their execution," 146 and the Framers explicitly so entrusted the Congress through the Necessary and Proper Clause. ${ }^{147}$ What is more, the "intrust" language affirms precisely the fiduciary understanding of Congress' role that the Framers intended to incorporate through the Necessary and Proper Clause.

Marshall's reading of the Necessary and Proper Clause in McCulloch has since become the classic interpretation of the Clause. Comstock, of course, has forced some rethinking of the meaning of the Necessary and Proper Clause, but it is important to emphasize that nothing in Comstock actively undermines McCulloch. In fact, Breyer's opinion explicitly reaffirms McCulloch, calling Marshall's well-known statement that when "the end be legitimate" and "within the scope of the Constitution, and all means which are appropriate, which are plainly adapted to that end, which are not prohibited . . . are constitutional" "language that has come to define the scope of the Necessary and Proper Clause.” 148

Comstock's evident approval of McCulloch indicates that the Court's most recent interpretation of the Clause should be read in light of - and be constrained by-the McCulloch test, rather than being read as a wholesale replacement for

\footnotetext{
${ }^{143}$ Indeed, it has been argued that, "John Marshall's opinion for the Court in McCulloch is an epitome of Pinkney's speech, stripped of its amplification and soaring rhetoric.” Stephen M. Shapiro, William Pinkney: The Supreme Court's Greatest Advocate (1999), available at http://www.appellate.net/articles/wilpin799.asp.

${ }^{144}$ McCulloch, 17 U.S. (4 Wheat.) at 383 (argument of William Pinkney).

${ }^{145} \mathrm{Id}$. at 406.

${ }^{146} I d$. at 408.

${ }^{147}$ Id. at 411-12 ("But the constitution of the United States has not left the right of congress to employ the necessary means, for the execution of the powers conferred on the government, to general reasoning. To its enumeration of powers is added, that of making 'all laws which shall be necessary and proper, for carrying into execution the foregoing powers, and all other powers vested by this constitution, in the government of the United States, or in any department thereof."”).

148130 S. Ct. 1949, 1956 (2010) (quoting McCulloch, 17 U.S. (4 Wheat.) at 421).
} 
McCulloch. As courts and commentators have begun to suggest, Comstock's five factors can be read as elaborations of McCulloch test requirements. In particular, the factors seem to be fleshing out the "means which are appropriate" and "plainly adapted" to a given enumerated constitutional end. ${ }^{149}$ But because the Comstock factors are vague, they have so far only added confusion to the meansend rationality test first established in McCulloch. What history of federal involvement in the area is "long" enough? What are sufficiently "sound reasons" to legislate? What makes a statute sufficiently "narrow in scope”?

The ambiguity inherent in the Comstock factors therefore brings greater attention to the underlying, enduring puzzle of the Necessary and Proper Clause: what does it mean for the fit between legislated means and enumerated end to be reasonable? As noted earlier, this question has become even more difficult in the aftermath of Comstock because Comstock explicitly rejected the requirement of a one-step removal limit between the chosen means and an enumerated constitutional end. ${ }^{150}$ And so it is to this question that the Article now turns.

\section{Three Readings of the Necessary and Proper Clause After Comstock}

This Section will focus on the deeper puzzle of Comstock left open since McCulloch: what does it really mean for a legislated means to be "plainly adapted" and "appropriate" for an enumerated end? ${ }^{151}$ At the same time, the Section will attempt to shed some additional light on Comstock's five considerations, because - though they might not map on perfectly to a means-end fit test - the considerations can be read to inform such a test.

In canvassing the range of possible means-end tests, this Section first evaluates two more extreme positions, either a rational basis test with substantial "bite" or an approach through which the judiciary largely abandons the field, and then explores possible intermediate positions. It ultimately concludes that an intermediate position informed by the Necessary and Proper Clause's fiduciary history-particularly a test asking whether Congress is acting as a proper fiduciary of the American people within the context of its enumerated powers-is the best way to bring meaning and clarity to the Clause after Comstock.

\footnotetext{
149 See, e.g., United States v. Kebodeaux, 634 F.3d 137, 143 (5th Cir. 2011) (explaining that Comstock's first and third factors are just proxies for considering whether a statute is reasonably adapted to an enumerated end); Gill v. Office of Pers. Mgmt., 699 F. Supp. 2d 374, 393 (D. Mass. 2010) (stating that the history factor is "only a proxy to determine 'the reasonableness of the relation between the new statute and pre-existing federal interests'”); Massachusetts v. U.S. Dep't of Health \& Human Servs., 698 F. Supp. 2d 234, 250 (D. Mass. 2010) (same).

${ }^{150}$ See supra text accompanying notes 44-46.

${ }^{151}$ See McCulloch, 17 U.S. (4 Wheat.) at 421.
} 


\section{1. "Rational Basis with Bite"}

The most aggressive reasonable interpretation of the requirement of a rational relationship between legislated means and constitutional ends is some form of rational basis test with bite, i.e., a test that is likely to find some nontrivial range of congressional legislation unconstitutional under the Necessary and Proper Clause. While the Clause post-Comstock may not require that the connection between legislated means and enumerated end be only one-step removed, that does not necessarily mean the connection between means and ends need not be a significant one. Especially if we read Comstock's five factors (which lend insight into whether a means really is rational) more like a test in which all or most of the considerations should be met for a statute to be constitutional, as Justice Thomas' dissent, ${ }^{152}$ Justice Alito and Justice Kennedy's concurrences, ${ }^{153}$ and some lower courts ${ }^{154}$ have indicated the factors might be read, we are left with a demanding constitutionality standard.

A rigorous rational basis test requiring all five of Breyer's factors to be satisfied would provide some degree of predictability because there would be five specific prongs to be met. But it still would not be especially clear, given the vagueness inherent in the various prongs. Thus it might be useful to draw analogies from other contexts in which rational basis tests have been given substantial bite. The most obvious candidate is the rational basis with bite test from the equal protection context, applied to certain classes not entitled to strict or even intermediate scrutiny, but which are nevertheless subject to some level of implicitly heightened judicial review. ${ }^{155}$ Such an implicitly heightened standard could be applied to require an active showing of rationality in the relationship between a legislated means and an enumerated end, perhaps as demonstrated through fit within Congress' broad legislative powers, the history of federal involvement in the area, the sound reasons for the statute, the statute's accommodation of state interests, and the statute's narrow scope. Yet when to actually apply the bite in this test is notoriously uncertain in the Equal Protection

\footnotetext{
${ }^{152}$ See supra text accompanying note 60.

${ }^{153}$ See supra Section I.b (noting the concurrences' concerns about the ambiguity of the majority's five-factor approach).

${ }^{154}$ See, e.g., supra text accompanying note 88.

${ }^{155}$ See, e.g., Romer v. Evans, 517 U.S. 620 (1996) (holding that a state constitutional amendment preventing any municipality from recognizing homosexuals as a protected class failed rational basis review); City of Cleburne v. Cleburne Living Center, Inc., 473 U.S. 432 (1985) (holding that a special use permit requirement for a group home for mentally disabled individuals failed rational basis review).
} 
context. ${ }^{156}$ And it would likely be equally uncertain when the bite should be applied to hold that Comstock's five factors are not met sufficiently to establish a true rational relationship between means and enumerated end.

Another context in which rational-basis-type tests have been given significant bite is in the "hard look" approach to the "arbitrary and capricious" standard for striking down administrative rulemaking. ${ }^{157}$ Especially given recent research suggesting that the history of the Necessary and Proper Clause may have been influenced in part by administrative law reasonableness principles that led directly to the arbitrary and capricious standard, ${ }^{158}$ looking to this jurisprudence may seem appropriate. By doing so, we might analogize the legislating Congress to the rulemaking agency, and suggest that, like an agency subject to hard look review, Congress should be held to a standard of substantive rationality in the relationship of its legislation with enumerated constitutional ends, again perhaps setting the Comstock factors as requisite benchmarks for such substantive rationality. But when hard look review is merited, and how exactly to apply it, may be as uncertain as in the case of equal protection's rational basis with bite test. $^{159}$

Thus, even using equal protection or administrative law analogies and the five Comstock prongs as a guide, without more certainty as to the content of those prongs, it would be hard to apply a rational basis with bite test in the Necessary and Proper context consistently. Nor, even if it did draw upon administrative "reasonableness" principles, does the approach directly incorporate the central history of the Necessary and Proper Clause in fiduciary principles. And, probably most importantly, such a stringent approach does not fit well with the most

\footnotetext{
156 See, e.g., Gerald Gunther, Foreword: In Search of Evolving Doctrine on a Changing Court: A Model for a Newer Equal Protection, 86 HARV. L. REV. 1, 46 (1972) (indicating that the rational basis with bite model "is relatively simple to describe, but the description may obscure difficulties in its application”); Jeremy B. Smith, Note, The Flaws of Rational Basis with Bite: Why the Supreme Court Should Acknowledge Its Application of Heightened Scrutiny to Classifications Based on Sexual Orientation, 73 FORDHAM L. REV. 2769, 2814 (describing rational basis with bite as a "heretofore elusive, undefined, and controversial" standard of review).

157 See, e.g., Motor Vehicle Manufacturers Ass'n of U.S., Inc. v. State Farm Mutual Automobile Insurance Co., 463 U.S. 29 (1983) (holding that modification of motor vehicle standard was arbitrary and capricious without a satisfactory, rational reason); National Tire Dealers \& Retreaders Ass'n, Inc. v. Brinegar, 491 F.2d 31 (D.C. Cir. 1974) (holding that a tire labeling regulation was arbitrary and capricious because there was no substantial relationship between the regulation and the statutory ends).

${ }^{158}$ See supra text accompanying notes 115-119; see also Lawson \& Seidman, supra note 115.

159 See, e.g., Jerry L. Mashaw, Richard A. Merrill \& Peter M. Shane, Administrative LAW: THE AMERICAN PUBLIC LAW SYSTEM 537-38 (6th ed. 2009) (considering confusion over procedural vs. substantive standards in Brinegar, difficulty distinguishing Brinegar from another case in which a regulation was upheld, and whether arbitrary and capricious review is really less demanding than substantial evidence review).
} 
plausible reading of Comstock. As discussed above, Breyer's five "considerations" are to be "taken together,"160 an approach that seems flexible, especially given the Justice's usual pragmatic and deferential perspective. ${ }^{161}$

\section{Abandon the Field}

Given the problems with a rigorous rational basis with bite approach, one might think that what Comstock actually suggests is that the courts should essentially abandon the field of policing exercises of Congress' legislative authority. After all, the post-sentence civil commitment statute upheld in Comstock is a striking exercise of congressional power. If Comstock's considerations are read only as considerations and not as a test, as seems to have been Breyer's intention, ${ }^{162}$ and we read strongly Breyer's point that there is no limit to the number of steps of logical separation between means and ends, the standard for upholding legislation as reasonable can become effectively a rubberstamp. Under this approach, as long as some argument can be made that there is a connection between legislated means and enumerated end, courts should defer to Congress.

This perspective is analogous to Justice Souter's dissent in United States $v$. Lopez, in which he argued that the Commerce Clause "substantial effects" jurisprudence had reached a point where the Court had essentially abandoned the field, as there were no longer manageable standards to apply in determining whether a given law "substantially affects" interstate commerce. ${ }^{163}$ For Souter, the Court had been right, since the "switch in time" in $1937,{ }^{164}$ to "defer to what is often a merely implicit congressional judgment that its regulation addresses a subject substantially affecting commerce 'if there is any rational basis for such a finding.",165 The reason? Judicial restraint. "In judicial review under the Commerce Clause,” Souter explained, "it reflects our respect for the institutional competence of the Congress on a subject expressly assigned to it by the

\footnotetext{
160130 S. Ct. 1949, 1956 (2010).

${ }^{161}$ See supra notes 34-43 and accompanying text.

${ }^{162}$ See supra note 160 and accompanying text.

${ }^{163}$ See 514 U.S. 549, 603 (1995) (Souter, J., dissenting).

${ }^{164}$ See, e.g., NLRB v. Jones \& Laughlin Steel Corp., 301 U.S. 1 (1937) (upholding the National Labor Relations Act's regulation of a steel corporation's labor practices, as legislation "substantially affecting" interstate commerce).

${ }^{165}$ Id. (emphasis added) (citing Hodel v. Virginia Surface Mining \& Reclamation Ass'n, Inc., 452 U.S. 264, 276 (1981); Presault v. ICC, 494 U.S. 1, 17 (1990)). Souter also warned: "The modern respect for the competence and primacy of Congress in matters affecting commerce developed only after one of this Court's most chastening experiences, when it perforce repudiated an earlier and untenably expansive conception of judicial review in derogation of congressional commerce power.” Id. at 604.
} 
Constitution and our appreciation of the legitimacy that comes from Congress' political accountability in dealing with matters open to a wide range of possible choices." ${ }^{266}$ Souter's theory, applicable to similar determinations outside the Commerce Clause context, may seem to fit well with Breyer's deferential Necessary and Proper Clause approach, seen in Comstock and in his separate dissent in Lopez, ${ }^{167}$ among other places.

But even Souter recognized the need for at least some rational basis for the relationship between legislation and interstate commerce, and allowing any congressional basis but the patently absurd to be deemed a rational fit between legislated means and enumerated end abandons almost all of the judiciary's role in interpreting the Necessary and Proper Clause, weakening the separation of powers function of judicial review in this context. Moreover, the fact that Justice Breyer expended so much effort elaborating considerations to justify his conclusion in Comstock may suggest that courts' Necessary and Proper Clause means-end fit analysis should be a serious one. As Justice Alito's Comstock concurrence warned: "The Necessary and Proper Clause does not give Congress carte blanche. Although the term 'necessary' does not mean 'absolutely necessary' or indispensable, the term requires an 'appropriate' link between a power conferred by the Constitution and the law enacted by Congress.”168

\section{An Intermediate Option}

Given the problems with both a very weak and a very strong reading of the requisite fit between legislated means and enumerated end under the Necessary and Proper Clause, it may be most appropriate to pursue an intermediate reading. Such a middle ground, more serious than the virtual blank check of the "abandon the field" approach and yet more deferential than the "rational basis with bite" approach, would almost certainly be more loyal to the majority's moderate and pragmatic approach implicit in Comstock. One way to give content to such an intermediate position is to look to the newly clarified history of the Necessary and Proper Clause, ${ }^{169}$ to craft a test that reflects original meaning.

Applying the history of the Necessary and Proper Clause in agency and fiduciary principles to design a means-end rationality test does not inevitably lead

\footnotetext{
${ }^{166} I d$.

${ }^{167}$ Id. at 616-17 ("Courts must give Congress a degree of leeway in determining the existence of a significant factual connection between the regulated activity and interstate commerce-both because the Constitution delegates the commerce power directly to Congress and because the determination requires an empirical judgment of a kind that a legislature is more likely than a court to make with accuracy.”).

168130 S. Ct. 1949, 1970 (2010) (Alito, J., concurring in the judgment).

${ }^{169}$ See supra Section III.a.
} 
to one particular test. The precise test emerging from the history depends on the level of generality from which the history is approached. A test at a lower level of generality might ask the question: is the means of legislation by the agent (Congress) of the kind the principal (the American people), if asked, would have approved in advance as a "necessary and proper" exercise of the agent's enumerated powers? ${ }^{170}$ This test emerges from the incidental powers doctrine that was a key source for the Necessary and Proper Clause, ${ }^{171}$ as it asks whether the Congress is properly legislating only in a manner incidental to its enumerated powers. There are, however, serious problems with such an approach. First, we must ask: which "American people” do we have in mind? If we are talking about Americans at the time of the founding, they probably would have approved of almost none of the legislated means later permitted, e.g., under the Commerce Clause, because there was at the time a very strong skepticism of central government power. ${ }^{172}$ Even if we are talking about the American people in contemporary perspective, as may be more reasonable, ${ }^{173}$ how do we know what they would have approved in advance? Though we might be confident that most contemporary Americans would approve a broader range of legislation than would Americans in the Founding generation, the "principal" is too diffuse to be confident about its preferences, particularly in any borderline situation. Thus, the test would fail in all the difficult cases-and so could hardly be considered judicially manageable.

As an alternative, a test drawing on the same history but framed from a higher level of generality could ask, from an objective, contemporary perspective, whether the legislative means chosen by Congress properly follows from an enumerated power, as judged by a determination of whether Congress is acting as a proper fiduciary of the American people. That is, is the Congress carrying out its fiduciary duties, within the context of its enumerated powers? This approach-which this Article calls a modern fiduciary theory of the Necessary and Proper Clause-draws directly on the history of the Clause in fiduciary and agency law, and, as the next Part will show, uses that history to give content to a

\footnotetext{
${ }^{170}$ Cf. Natelson, supra note 108 , at $82-83$.

${ }^{171}$ See id.

172 See, e.g., Gordon S. WoOd, The Creation of the AmERICAN RePuBlic 1776-1787, at 559 ("Yet amidst all of the jumble of explanations presented during the ratification debates there was one that the Federalists repeatedly came back to: the need to distribute and separate mistrusted government power.”).

${ }^{173}$ It is worth noting here that even arch-originalist Justice Scalia has implied that original intent must be adaptable as applied to new technology and contexts. See, e.g., Kyllo v. United States, 533 U.S. 27, 33-34 (2001) (Scalia, J.) ("It would be foolish to contend that the degree of privacy secured to citizens by the Fourth Amendment has been entirely unaffected by the advance of technology.”).
} 
judicially manageable modern test that follows from Comstock, and may solve both puzzles embedded in that decision.

\section{A Modern Fiduciary Theory of the Necessary \& Proper Clause}

This Part elaborates the final means-end test introduced in the previous Part: the modern fiduciary theory of the Necessary and Proper Clause. It argues, first, that the modern fiduciary theory is a natural elaboration of the Comstock opinion that clarifies both puzzles of that opinion, the deeper puzzle of what means-end fit should be required under the Necessary and Proper Clause, and the puzzle on the surface of the opinion as to how to interpret Breyer's five considerations. It does so by assuming adherence to Congress' fiduciary duties as agents of the American people as the requirement for a reasonable fit between legislated means and constitutional ends, and reading the five considerations as non-binding, pragmatic factors for interpreting Congress' fiduciary duties.

This Part further argues that the modern fiduciary theory has at least two other advantages: it presents an appropriate middle ground between the two extremes laid out in Part III (an aggressive rational basis with bite test on the one hand, and abandoning the field of judicial enforcement on the other). Moreover, the modern test is adaptable over time, yet at the same time rooted in the original principles underlying the Necessary and Proper Clause. While manageability might remain a challenge under the modern fiduciary theory, it should be less of a problem than under other approaches because well-developed existing fiduciary principles provide ample guidance. A case study of the modern fiduciary theory applied to the PPACA - which almost certainly would be held constitutional under the modern fiduciary theory - demonstrates how the test can be applied in a manageable, straightforward way, finally bringing meaning back to the Necessary and Proper Clause.

\section{A. The Test}

In order to apply the modern fiduciary theory and answer the question of whether Congress is carrying out its fiduciary duties to the American people, within the context of its enumerated powers, it is important to clarify what fiduciary duties are applicable. This Section begins by reviewing the fiduciary duties the Framers of the Necessary and Proper Clause recognized, and proceeds to show that overlapping duties emerge from Comstock's five considerations. As 
suggested in the historical analysis above, ${ }^{174}$ the Constitution at large "should be read through a fiduciary lens" because "[a] central purpose of the document was to adopt for America a fiduciary government whose conduct would mimic that of the private-law fiduciary," in honoring duties to "exercise reasonable care, remain loyal to the public interest, [and] exercise . . . power in a reasonably impartial manner." 175 This vision, shared by Whigs and many Tories, had roots in classical political-both republican and social compact-theory. ${ }^{176}$ The language of the Necessary and Proper Clause in particular was evocative of this fiduciary vision. As such, the means-end rationality test under the Clause should be read to incorporate the fiduciary duties widely accepted at the time, ${ }^{177}$ including reasonable impartiality, loyalty, good faith, care, and remaining within authority. ${ }^{178}$

Each of these duties can also be understood to emerge from the considerations applied in Comstock. The duty to remain within authority is incorporated in the first and second Comstock considerations. According to the first consideration, Congress has "broad authority to enact legislation . . . 'based on one or more"” enumerated power(s). ${ }^{179}$ The connection of this factor to the duty to remain within authority is self-evident: legislating only based on enumerated powers is the one fundamental limitation of the Necessary and Proper Clause, and the fundamental requirement for Congress to remain within the constitutional authority it was granted. Under Comstock's second consideration, Congress should consider the history of federal involvement in an arena, to help

\footnotetext{
${ }^{174}$ See supra Section III.a.

${ }^{175}$ Natelson, supra note 108, at 52-53. For a modern fiduciary theory of government, see FoxDecent, The Fiduciary Nature of State Legal Authority, supra note 8.

${ }^{176}$ See, e.g., John LoCKe, The SeCOND Treatise Of Civil Governnent (Thomas I. Cook ed., 1947) (1690) ("The power of assembling and dismissing the legislative, placed in the executive, gives not the executive a superiority over it, but is a fiduciary trust for the safety of the people . . . .”); Jean-Jacques Rousseau, The Social Contract 168 (Rose M. Harrington trans., Knickerbocker Press 1893) (1762) ("In all true democracies, the magistracy is not an advantage, but an onerous duty . . . ."); see also Natelson, supra note 108, at 53-55 (noting numerous influences on the Founders viewing government as a fiduciary or trust-based relationship, and the resulting trust-based understanding of the Founders' role).

177 See Natelson, supra note 108, at 57-60. As noted, supra note 123 and accompanying text, the law of fiduciary duties has not changed dramatically since the Founding.

${ }^{178}$ See Natelson, supra note 108, at 119. It is worth emphasizing here that these fiduciary duties, like the Comstock decision itself, should be understood in a manner deferential to the agent, i.e., Congress. The modern fiduciary theory assumes a business judgment rule-type presumption, as for corporate fiduciaries, and the duty of care, for instance, should not be understood to adopt the more aggressive (and largely discredited) standard of Smith v. Van Gorkom, 488 A.2d 858 (Del. 1985). For critiques of Van Gorkom, see, for example, Daniel Fischel, The Business Judgment Rule and the Trans Union Case, 40 Bus. LAw. 1437, 1455 (1985) (calling the decision "one of the worst ... in the history of corporate law.").

179130 S. Ct. 1949, 1956 (2010) (quoting United States v. Morrison, 529 U.S. 598, 607 (2000)).
} 
determine "the reasonableness of the relation between the new statute and preexisting federal interests." ${ }^{180}$ Here too, Congress is being expected to act only within its authority, as reflected in past practice, i.e., previous spheres of activity deemed appropriate for federal legislation.

The other Comstock considerations can also be read to reflect some combination of fiduciary duties owed by Congress. Narrowness of scope, for instance, reflects the duty of care, as due care requires reasonably careful, nonnegligent drafting. The narrow scope factor also embodies the duty to remain within authority, as the legislation must be reasonably narrowly tailored to an enumerated power. The accommodation of state interests factor reflects care in avoiding inappropriate intrusion in areas of state concern, and good faith and impartiality in Congress' role as stewards of a federal system.

Finally, Comstock's sound reasons for enactment factor is explicitly described in fiduciary terms. ${ }^{181}$ Duties of care, loyalty, good faith, and impartiality are all inherent in the requirement that legislation be based on sound reasons "in light of the Government's custodial interest in safeguarding the public." "182 As the Court explains in discussing the sound reasons for enactment of $\S 4248$, “at common law, one 'who takes charge of a third person' is 'under a duty to exercise reasonable care.",183 Implicit in this recognition is a linked appreciation that one-including Congress- “taking charge" as a fiduciary is also under a duty to exercise loyalty, good faith, and impartiality in his fiduciary role.

\section{Benefits}

The modern fiduciary theory is a natural reading of the Necessary and Proper Clause post-Comstock, as confirmed by the fit between Comstock's factors and traditional fiduciary duties, and the content these duties provide to a test of means-end fit. But the modern fiduciary reading has two other important benefits: first, its effective moderation between the two extremes of a test with substantial "bite" and abandoning the field; and, second, its flexibility over time, while being rooted in historical principles on which the Necessary and Proper Clause was based. As for moderation, the modern fiduciary theory balances separation of powers concerns that demand that courts not give up having any real role in interpreting means-ends fit under the Necessary and Proper Clause, ${ }^{184}$ with

\footnotetext{
${ }^{180} \mathrm{Id}$. at 1958.

${ }^{181}$ See id. at 1961-62, 1965. The context is linked to Congress' role under $\S 4248$ as custodian of federal prisoners, but the language is sweeping enough to apply more broadly. See id.

${ }^{182}$ Id. at 1965.

${ }^{183}$ Id. at 1961 (quoting RESTATEMENT (SECOND) OF TORTS § 319 (1963-1964)).

184 The Court would have to give up such a role if the "abandon the field" alternative were applied. See supra Subsection III.c.ii.
} 
due deference to Congress, ${ }^{185}$ which-as a whole-almost certainly is most often operating with loyalty and good faith, and generally is also operating with care and impartiality.

As for flexibility over time, the modern fiduciary theory does not suffer the flaws inherent in the alternative lower level of generality test discussed in Part III that asks whether the means of legislation by Congress is of the kind the American people, if asked, would have approved in advance. ${ }^{186}$ First, the modern fiduciary theory, asking whether Congress is, today, objectively acting within its fiduciary duties, does not require a nearly impossible historical inquiry into how any bill would have been perceived by Americans at the time of the Founding. (Nor does it require an almost-as-impractical inquiry into whether modern Americans, overall, would have approved a given law in advance.) Second, and perhaps more importantly, the modern fiduciary theory is not limited by the relatively narrow scope for federal legislation citizens of the Founding generation would have recognized. What has been deemed a reasonable exercise of congressional power has expanded over time. ${ }^{187}$ The modern fiduciary theory is able to adjust for this in a dynamic way, while remaining true to the roots of the Necessary and Proper Clause in fiduciary principles. ${ }^{188}$ In doing so, the modern fiduciary theory allows the Clause to uphold, in Chief Justice Marshall's words from McCulloch (reiterated at the conclusion of Comstock), "a constitution intended to endure for ages to come, and, consequently, to be adapted to the various crises of human affairs.”189

\section{Challenges}

\footnotetext{
${ }^{185}$ Congress would be denied this deference under an alternate test with too much bite. See supra Subsection III.c.i.

${ }^{186}$ See supra notes $170-171$ and accompanying text.

187 This is especially evident in the Commerce Clause jurisprudence. See, e.g., Gonzales v. Raich, 545 U.S. 1 (2005); Katzenbach v. McClung, 379 U.S. 294 (1964); Heart of Atlanta Motel v. United States, 379 U.S. 241 (1964); Wickard v. Filburn, 317 U.S. 111 (1942); United States v. Darby Lumber Co., 312 U.S. 100 (1941); NLRB v. Jones \& Laughlin Steel Corp., 301 U.S. 1 (1937). But see United States v. Morrison, 529 U.S. 598 (2000); United States v. Lopez, 514 U.S. 549 (1995).

${ }^{188}$ It is worth noting that this approach is roughly in line with Jack Balkin’s "living originalism,” which recognizes that the Constitution is a living document, but attempts to retain fidelity to the original meaning of constitutional text and principle. See BALKIN, supra note 7, at 3.

${ }^{189}$ United States v. Comstock, 130 S. Ct. at 1965 (quoting McCulloch v. Maryland, 17 U.S. (4 Wheat.) 316, 415 (1819)). Justice Breyer is a leading advocate of such a dynamic understanding of the Constitution. See, e.g., BREYER, ACTIVE LIBERTY, supra note 35, at 25 (indicating that his book is meant to "help[] interpret the Constitution-in a way that helps to resolve problems related to modern government”).
} 
One weakness of the modern fiduciary theory is that it does not completely solve the judicial manageability problems currently plaguing the Necessary and Proper Clause means-end rationality analysis. How exactly does one know when Congress is carrying out its fiduciary duties to the American people, and when it is not? There will always be a judgment call inherent in answering this question (and probably in applying any alternative standard, unless the judiciary "abandons the field").

But an advantage of the theory proposed here is that agency and corporate law principles understood by the Framers themselves provide a reference guide for interpreting fiduciary duties. The alternate test asking what exercises of Congress' legislative power would have been approved in advance will always be confounded by the conflicting preferences of the American people doing the approving. ${ }^{190}$ Other rationality standards like rational basis with bite and hard look arbitrary and capricious review have also been critiqued for their amorphousness. ${ }^{191}$ In contrast, the modern fiduciary theory allows judges to look to a rich history of fiduciary-based thinking, including a common law jurisprudence that remains similar today to the way it looked in the Framers' era. ${ }^{192}$

\section{B. Case Study: The Affordable Care Act}

Before concluding, it will be useful to offer a case study of how the modern fiduciary theory might be applied in practice. There is no more pressing issue to which the theory might be applied than the debate on the constitutionality of the PPACA's individual mandate. It is important to note at the outset that the constitutionality of the mandate may not ride so much on the Necessary and Proper Clause as the Commerce Clause, ${ }^{193}$ or at least in the case currently before the Court, preliminary jurisdictional questions under the Anti-Injunction Act. ${ }^{194}$

\footnotetext{
${ }^{190}$ See supra Subsection III.c.iii.

${ }^{191}$ See supra notes 156 \& 159 and accompanying text.

${ }^{192}$ See supra note 123 and accompanying text.

${ }^{193}$ See, e.g., Liberty Univ. v. Geithner, No. 6:10-cv-00015-nkm, 2010 WL 4860299, at *11 (W.D. Va. Nov. 30, 2010) ("Because I find that the employer and individual coverage provisions are within Congress' authority under the Commerce Clause, it is unnecessary to consider whether the provisions would be constitutional exercises of power pursuant to the General Welfare Clause or the Necessary and Proper Clause.”).

${ }^{194}$ The Fourth Circuit and Judge Kavanaugh's dissent in the D.C. Circuit focus on the AntiInjunction Act as a bar to suit challenging the individual mandate before it has taken effect. Seven-Sky v. Holder, No. 11-5047, 2011 WL 5378319, at *17-18 (D.C. Cir. Nov. 8, 2011) (Kavanaugh, J., dissenting as to jurisdiction); Liberty University v. Geithner, No. 10-2347, 2011 WL 3962915 (4th Cir. Sept. 8, 2011); see also supra note 84 (listing PPACA cases in the lower courts that largely avoided Necessary and Proper Clause analysis).
} 
And even if the Necessary and Proper Clause is the focus of analysis, some have argued that regulation of "inactivity" (i.e., a decision not to buy healthcare) is an unconstitutional end, ${ }^{195}$ such that a court need not even reach analysis of the means-end fit. But, to many, including this author, "the constitutionality of the 'end' - that is, the Act's insurer regulations - is both clear and unchallenged."196 The Supreme Court has recognized insurance as commercial activity, ${ }^{197}$ and even Judge Vinson, in striking down the individual mandate, recognized "the 'end' of regulating the health care insurance industry . . . is clearly legitimate and within the scope of the constitution." ${ }^{\text {"198 }}$ There is, moreover, no precedent for a fundamental activity-inactivity distinction in Commerce Clause jurisprudence. ${ }^{199}$

What is somewhat more complicated is whether there is sufficient rationality in the relationship between means (i.e., the individual mandate) and end (i.e., regulation of commerce). To answer this question, the modern fiduciary theory brings to bear a new and valuable toolset. Applying this approach, the critical question is whether Congress was acting as a proper fiduciary of the American people, within the context of its enumerated powers (here, the commerce power), in enacting the individual mandate. First, did Congress remain within its authority? If regulating health insurance is within the Commerce Clause power, as is generally assumed, it would certainly seem that Congress did so remain. ${ }^{200}$ But did Congress exercise due care, and fulfill its duties of loyalty,

195 See, e.g., Virginia ex rel. Cuccinelli v. Sebelius, 728 F. Supp. 2d 768, 771-72 (“[T]he Commonwealth argues that requiring an otherwise unwilling individual to purchase a good or service from a private vendor is beyond the boundaries of congressional Commerce Clause power.”), vacated, 656 F.3d 253 (4th Cir. 2011).

${ }^{196}$ See Florida v. U.S. Dep’t of Health \& Human Servs., No. 3:10-cv-91-RV/EMT, 2011 WL 3519178, at *102 (11th Cir. Aug. 12, 2011) (Marcus, J., concurring in part and dissenting in part); see also Koppelman, supra note 5, at 3 (describing the "obvious constitutionality" of the mandate under the Commerce Clause).

${ }^{197}$ Indeed, it has noted that "[p]erhaps no modern commercial enterprise directly affects so many persons in all walks of life as does the insurance business.” United States v. Se. Underwriters Ass'n, 322 U.S. 533, 540 (1944).

${ }^{198}$ Florida ex rel. Bondi v. U.S. Dep't of Health \& Human Servs., 780 F. Supp. 2d 1256, 1298 (N.D. Fla. 2011), aff'd in part, rev'd in part sub nom. Florida v. U.S. Dep't of Health \& Human Servs, 648 F.3d 1235 (11th Cir. 2011).

${ }^{199}$ See Koppelman, supra note 5, at 6.

${ }^{200}$ For a historically rooted analysis that reaches a different conclusion, see Lawson \& Kopel, supra note 5. See also Brief of Authors of The Origins of the Necessary and Proper Clause (Gary Lawson, Robert G. Natelson \& Guy Seidman) and the Independence Institute as Amici Curiae in Support of Appellees, Urging Affirmance, Florida v. U.S. Dep't of Health \& Human Servs., No. 11-11021 (11th Cir. 2011) [hereinafter Authors Brief]. Lawson and Kopel's essay and Lawson and his fellow amici's brief argue that incidental powers must be "subordinate" to or "less worthy" than enumerated powers and "[t]he power to compel private persons to engage in commercial transactions with other private persons is not an incidental power" under this standard. Lawson \& Kopel, supra note 5, at 267, 279-80; see also Authors Brief, supra, at 14. Rather, "[t]he power to 
good faith, and impartiality? Loyalty and good faith seem easy. If there were evidence of self-dealing or bad faith among members of Congress passing the PPACA, the many opponents of the law would almost certainly have broadcast it. Similarly, there is no evidence the individual mandate was not carefully designed to effectively reform the healthcare insurance market, and assure that all Americans were covered.

The one fiduciary duty that might be open to some question is the duty of impartiality. Naturally, some "principals," e.g., older, less healthy Americans, benefit from the mandated coverage more than others, at least in the short term. But in the longer term, and in a broader sense, the individual mandate is in the best interests of all Americans, each of whom benefits from a system that functions effectively and covers them all through their own old age and declining health. Further, Congress plainly did not intend any favoritism in enacting the mandate. $^{201}$

In the end, then, the modern fiduciary approach leaves no question that the individual mandate is a rational means for carrying out Congress' enumerated end

compel the purchase of a product is as great or greater than the power to regulate voluntary commerce.” Authors Brief, supra, at xiii. By Lawson and Kopel's own admission, however, these interpretive conclusions do not necessarily follow from the broader historical project in LAWSON ET AL., supra note 6. See Lawson \& Kopel, supra note 5, at 270 ("[W]e do not claim that all of the book's authors would necessarily endorse all of the modern uses that we make of their purely originalist research.”). Indeed, anyone who read the Necessary and Proper Clause in the dynamic manner assumed in this Article would not feel limited by the narrow eighteenth century understanding of what powers can be "incidental" that is relied upon by Lawson. If, for example, criminalizing drugs grown in one's backyard for personal consumption can be "incidental" to the Commerce Clause power today, see Gonzales v. Raich, 545 U.S. 1 (2005), it seems unreasonable to say imposing a penalty for not purchasing health insurance (and thereby contributing to a breakdown in the national health insurance system) cannot be incidental. Andrew Koppelman adds, in a response to Lawson and Kopel, that Lawson and Kopel's reading of what is "subordinate" is "obscure even on [its] own terms." "It is mysterious," Koppelman explains, "how we are to know whether the power to impose a penalty for going without health insurance is less 'dignified' or 'worthy' than the power to regulate interstate commerce." Andrew Koppelman, Bad News for Everybody: Lawson and Kopel on Healthcare Reform and Originalism, 121 YALE L.J. ONLINE 515, 515 (forthcoming 2012).

${ }^{201}$ Gary Lawson and David Kopel imply that the individual mandate breaches the duty of impartiality, because it "compels transactions with a favored oligopoly of insurance companies." Lawson \& Kopel, supra note 5, at 267; see also Authors Brief, supra note 200, at 27-30. But any such implication is inapplicable under the modern fiduciary theory because the modern theory asks whether Congress is being a proper fiduciary of the American people, not insurance companies. And the American people overall are treated impartially under the individual mandate, even if insurance companies may not be. Even if Lawson and Kopel were read also to assume that the individual mandate breached a duty of impartiality to the American people, as Andrew Koppelman writes in response to Lawson and Kopel, in fact, "Congress is trying to make sure that everyone equally has access to adequate and affordable health care. Lawson and Kopel have not explained why that is not 'to treat them all fairly.'” Koppelman, supra note 200, at 521. 
of regulating commerce. As such, Comstock, read in light of the modern fiduciary theory and the deferential approach that almost certainly inspired its considerations, need pose no basic challenge to the individual mandate. Congress was acting within its authority and with impartiality, loyalty, good faith, and care in enacting the law, which addresses a national crisis with a very substantial effect on interstate commerce.

\section{ConCLUSION}

This Article began with two puzzles emerging from the Comstock decision. The first - what to make of the Justice Breyer's five "considerations" in that case moving forward-proved relatively simple. In light of Justice Breyer's usual pragmatic and deferential approach, there is no reason to read his five considerations in Comstock as any more than precisely what he calls them: considerations. They are not meant to constrain, but to explain.

Yet in attempting to make sense of Comstock, the Article identified a deeper puzzle of the Necessary and Proper Clause, bubbling below the surface since McCulloch, and reemerging in Comstock itself: when any given legislative act should be understood to follow reasonably from an enumerated constitutional power. The solution to this puzzle was buried somewhat deeper, in the historical roots of the Necessary and Proper Clause in the fiduciary theory that was pervasive in the world of the Framers. The Article has shown that this original meaning can give content to a means-end test that follows logically from Comstock and is at the same time manageable, moderate, and modern-that is, informed by original meaning, but dynamic enough not to be unduly weighed down by it. In doing so, the Article has attempted to protect and adapt a Clause "without the substance of [which]," in Madison's words, "the whole constitution would be a dead letter.",202

\footnotetext{
${ }^{202}$ THE FedERAList No. 44, at 322 (James Madison) (Cynthia Brantley Johnson ed., 2004).
} 